УДК 553.2: $549.283(571.52)$

\title{
ЗОЛОТО-СУЛЬФИДНО-КВАРЦЕВОЕ МЕСТОРОЖДЕНИЕ БАРСУЧИЙ (СЕВЕРО-ВОСТОЧНАЯ ТУВА): МИНЕРАЛОГО-ГЕОХИМИЧЕСКИЕ ОСОБЕННОСТИ И УСЛОВИЯ ОБРАЗОВАНИЯ
}

\author{
Кужугет Ренат Васильевич', \\ rkuzhuget@mail.ru
}

Прокопьев Илья Романович ${ }^{2,3}$, prokopev_ilya@mail.ru

Редина Анна Андреевна², anna-red@outlook.com

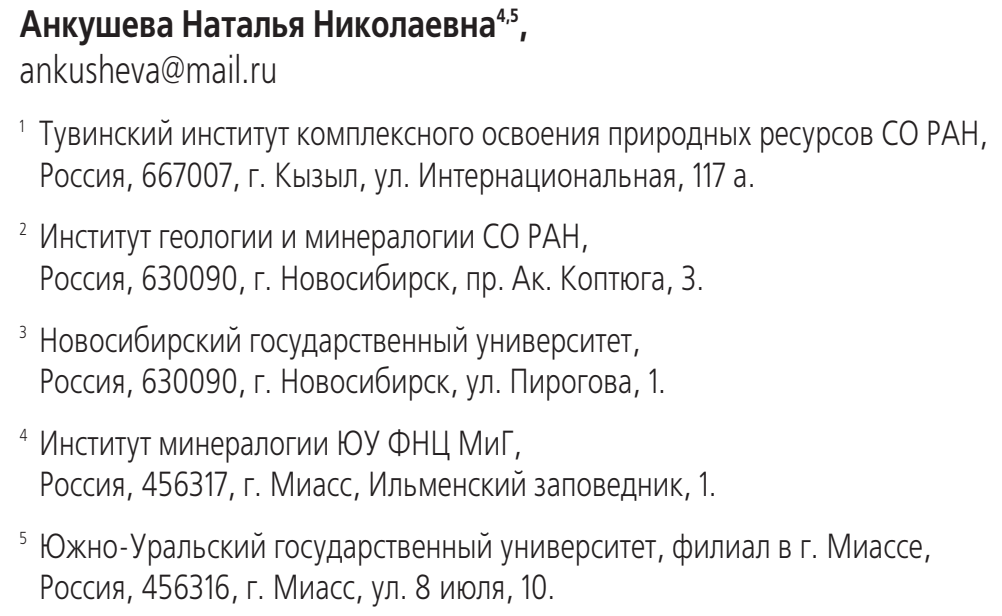

Золоторудные объекты в скарнах широко распространены в геологических структурах Восточной Тувы, но их промышленная оценка сопряжена со значительными трудностями из-за слабой изученности их минералого-геохимических особенностей. Актуальность исследования обусловлена необходимостью расшифровки генезиса и условий образования золоторудных объектов, локализованных в скарнах.

Цель: установление минералого-геохимических особенностей и условий формирования руд месторождения Барсучий в Северо-Восточной Туве.

Методы: полевые исследования, детальные минералогические исследования с изучением рудной минерализации в полированных шлифах (аншлифах) с помощью сканирующего электронного микроскопа Tescan Vega 3 sbu с ЭДС Oxford Instruments $X$-act. PT-условия формирования минеральных ассоциаций определялись термобарогеохимическими методами.

Результаты. Установлено, что золоторудная минерализация на месторождении Барсучий является постскарновой и имеет гидротермальный генезис, образуя прожилково-вкрапленное и прожилковое оруденение штокверкового типа в диоритах, контактовых (роговики, скарны) и гидротермально-метасоматических породах. Околорудные процессы на месторождении выражены в березитизации и лиственитизации кварцевых диоритов, скарнов и карбонатных пород. Отложение самородного золота происходило в две стадии. По составу продуктивных минеральных ассоциаций Барсучий отвечает золото-пирротин-пирит-халькопиритовому типу с калаверитом АuTe, петцитом $\mathrm{Ag}_{3} \mathrm{AuTe} \mathrm{e}_{2}$, гесситом $\mathrm{Ag}_{2}$ Tе и минералами ряда теллуровисмутит-теллурантимон. Рудоотложение золота на месторождении происходило из водных растворов с хлоридами $\mathrm{Na}$ и $\mathrm{K}$, содержащих $\mathrm{CO}_{2}$ и $\mathrm{CH}_{4}, \mathrm{C} \mathrm{CO}^{-}$ лёностью 1,7-10,5 мас. \% NaCl-экв. при изменении окислительно-восстановительного потенциала среды при вариациях $f_{2}$, $\mathrm{fSe}_{2}, \mathrm{fTe}_{2}$ и снижении температуры рудоносного флюида (первая продуктивная стадия $-360-280{ }^{\circ} \mathrm{C}$, вторая $-320-240{ }^{\circ} \mathrm{C}$ ). По минералого-геохимическим особенностям месторождение Барсучий относится к малосульфидной золото-сульфидно-кварцевой формации и близко к месторождениям золото-висмутового геохимического типа.

Ключевые слова:

Самородное золото, теллуриды, флюидные включения, кварц, Тува.

\section{Введение}

Геолого-съёмочными и поисковыми работами 1963-1971 гг. на площади Тарданского рудного узла (ТРУ) выявлены золоторудные объекты в скарнах (Тардан, Копто, Барсучий, Соруглуг-Хем, Правобережное) и березитах (Тардан-2), а также ряд мелких проявлений и многочисленные пункты минерализации золота. В региональном плане ТРУ расположен на юге Алтае-Саянской складча- той области и приурочен к краевой северо-западной части Каахемского полихронного гранитного батолита и одноименной зоны глубинных разломов. Золоторудные рудопроявления и месторождения ТРУ приурочены к зоне контакта Копто-Байсютского габбро-диорит-плагиогранитного массива раннетаннуольского комплекса $\left(\mathrm{O}_{1} t n\right)$ с вулканогенно-карбонатными породами туматтайгинской $\left(\mathrm{R}-\mathrm{C}_{1} t t\right)$ и тапсинской свит $\left(\mathrm{C}_{1} t p\right)$. В зоне экзо- 
контакта Копто-Байсютской интрузии вмещающие карбонатные породы рифея и раннего кембрия интенсивно скарнированы. Золотое оруденение в рудном узле контролируется оперяющими разрывными нарушениями Каахемского глубинного разлома и пространственно совмещено со скарновыми залежами сложного строения [1-3].

На Тарданском месторождении ТРУ гидротермальный золоторудный этап сопровождается интенсивным тектоническим дроблением скарнов, апоскарновых магнетит-тремолитовых метасоматитов и внедрением малых тел и даек гранодиоритов и гранит-порфиров раннетаннуольского комплекса $\left(\mathrm{O}_{1} t n\right)$, с которыми связан постмагматический рудоносный гидротермальный процесс, т. е. золотое оруденение является постскарновым и пространственно связано со скарновой формацией $[1,2]$. Возраст плагиогранитов Копто-Байсютского массива, определённый по биотиту $\mathrm{Ar} / \mathrm{Ar}$ ме-

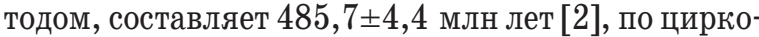
нам U-Pb методом- 479 2 млн лет [4]. Возраст даек гранит-порфиров раннетаннуольского комплекса $\left(\mathrm{O}_{1} t n\right)$, секущих скарны и апоскарновые метасоматиты и парагенетически связанных с золоторудной минерализацией в ТРУ, был определён $\mathrm{Ar} / \mathrm{Ar}$ методом по биотиту и составил $484,2 \pm 4,3$ млн лет, а возраст золотого оруденения золото-висмут-теллуридной минерализации месторождения Тардан, определённый $\mathrm{Ar} / \mathrm{Ar}$ методом по серициту из кварцевых прожилков минерализованных зон дробления, составляет $481 \pm 6,1$ млн лет, что соответствует раннему ордовику [2]. Предполагается, что 30лоторудные объекты ТРУ являются производными единой рудно-магматической системы [1].

\section{Методика исследований}

Образцы руд отобраны из коренных выходов месторождения. Химический состав минералов определялся методом сканирующей электронной микроскопии (Tescan Vega 3 sbu с ЭДС Oxford Instruments X-act, аналитик И.А. Блинов, ИМин ЮУ ФНЦ МиГ, г. Миасс). Для разделения золота на группы применена следующая классификация [5]: весьма высокопробное золото (1000-950 \%о), высокопробное золото (950-900), среднепробное золото (900-800), низкопробное золото (800-700), минеральные формы золота - электрум (700-300) и кюстелит (300-100), а также Аu-содержащее серебро $-<100 \%$. Условия образования минеральных ассоциаций изучались термобарогеохимическими методами исследований. Исследования флюидных включений проведены на базе АЦ ИГМ CO РАН (г. Новосибирск) методами микротермометрии с использованием микротермокамеры TMS-600 (Linkam). Интерпретация температур эвтектики флюидных включений проводилась согласно данным А.С. Борисенко [6]. Концентрация растворов включений определялась по температуре плавления льда [7]. Определение отношений стабильных изотопов серы в пирите выполнено в ЦКП многоэлементных и изотопных исследований
CO РАН с использованием газового масс-спектрометра Finnigan MAT Delta в режиме двойного напуска (г. Новосибирск, аналитики В.Н. Реутский, M.Н. Колбасова). Значения $\delta^{34} \mathrm{~S}$ приведены в промилле (\%o ) относительно стандарта CDT.

\section{Геологическое строение месторождения}

Месторождение Барсучий расположено в центральной части ТРУ, на левобережье р. Бай-Сют (рис. 1). Золоторудная минерализация на месторождении была выявлена во время геолого-съёмочных и поисковых работ на рудное золото 1965-1967 гг. в пироксен-гранатовых скарнах, развивающихся на контакте диоритов раннетаннуольского комплекса $\left(\mathrm{O}_{1} t n\right)$ с известняками тапсинской свиты $\left(\epsilon_{1} t p\right)$. Предшественниками это оруденение относилось к золото-скарновой формации [3].

Участок Барсучий, включающий одноимённое месторождение и два перспективных рудопроявления (Восточный и Южный Барсучий), представляет собой крупное $\left(6 \mathrm{\kappa M}^{2}\right)$ «провисание» кровли Копто-Байсютского массива раннетаннуольского комплекса $\left(\mathrm{O}_{1} t n\right)$ среди осадочно-вулканогенных пород туматтайгинской свиты $\left(\mathrm{R}-\mathrm{G}_{1} t t\right)$, представленных кварцевыми порфирами и их туфами $\mathrm{c}$ прослоями доломитов и известняков (маломощные сильно вытянутые ленточные тела северо-западного простирания), местами перекрытыми известняками тапсинской свиты $\left(\mathrm{C}_{1} t p\right)$.

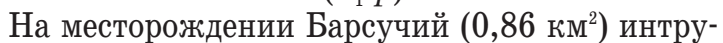
зивные породы представлены диоритами, кварцевыми диоритами и плагиогранитами, которые выполняют апофизу Копто-Байсютского массива. На контактах интрузивного массива с осадочно-вулканогенными породами наблюдаются значительные масштабы скарнирования с наложенной гидротермальной минерализацией. Оруденение золота контролируется разрывными нарушениями субмеридионального направления (рис. 1).

Лицензиями на геологическое изучение, разведку и добычу рудного золота в ТРУ располагает 000 «Тардан Голд» (учредитель - Auriant Mining AB, Швеция). В 2014 г. компанией были завершены геологоразведочные работы на участке Барсучий, и в 2015 г. начата промышленная отработка месторождения.

В ходе геологоразведочных работ на месторождении Барсучий выявлено 4 рудных тела. Они выходят за пределы скарнов, апоскарновых метасоматитов и продолжаются в пропилитах и пропилитизированных диоритах. Основное рудное тело погружается под толщу карбонатных пород в восточном направлении под углом около $65^{\circ}$ и залегает в виде линзы субмеридионального направления длиной 180 м при мощности 5-21 м (в среднем, 14 м). Согласно данным магнитной и геохимической съемки, зона скарнов простирается на 700 м к северо-западу, следовательно, рудное тело продолжается вдоль контакта. Среднее содержание Аи в рудных телах варьирует от 2,36 до 5,38 г/т. Для руд месторождения характерна $\mathrm{Au}-\mathrm{Cu}-\mathrm{Ag}-\mathrm{Bi}-\mathrm{Te}-\mathrm{As} \pm \mathrm{Sb} \pm \mathrm{Zn}$ геохимическая специализация. 


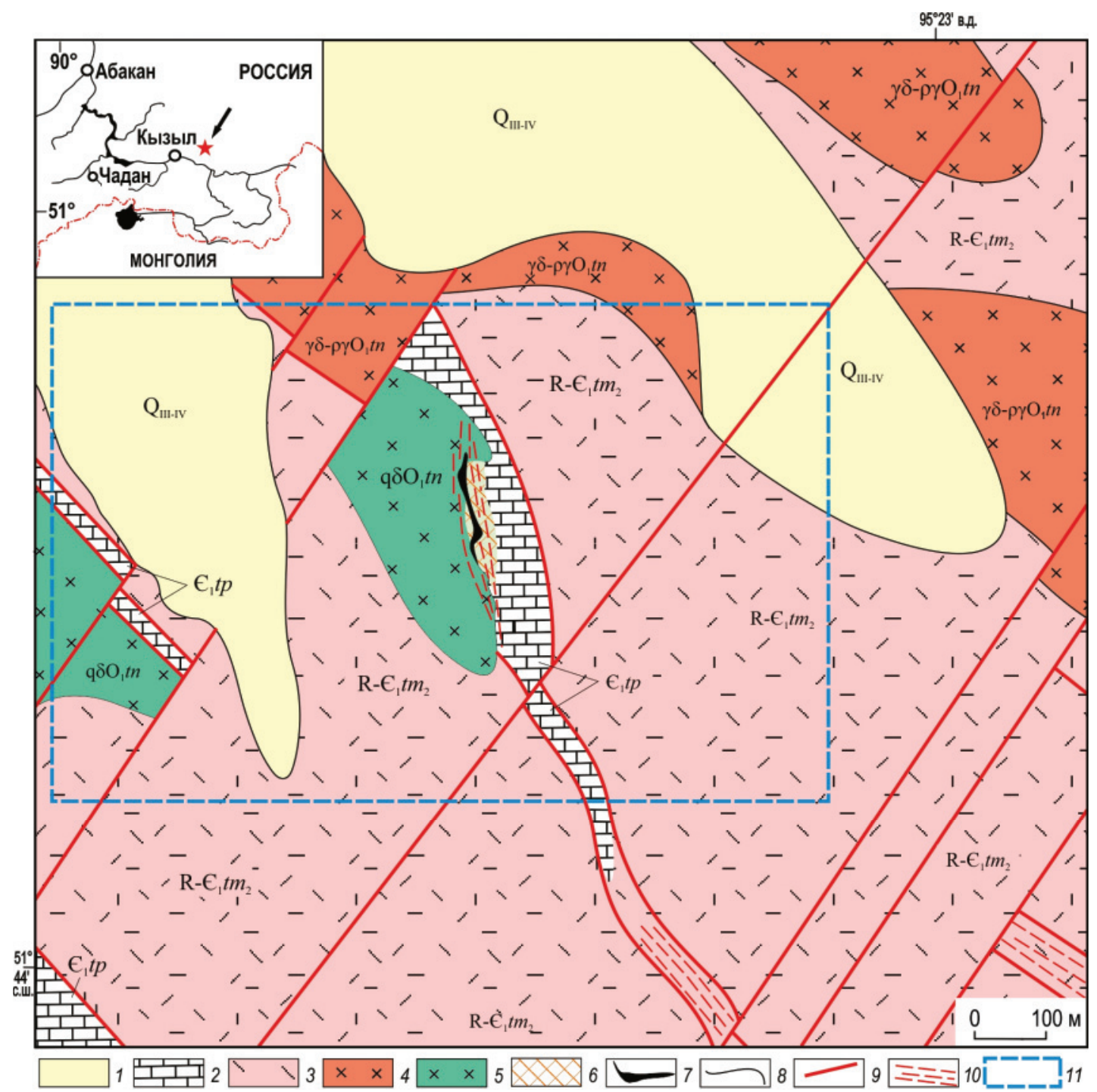

Pис. 1. Схема геологического строения месторождения Барсучий (по данным [3] с изменениями): 1 - делювиальные и пролювиальные отложения $\left(Q_{\text {ш-гу }}\right) ; 2$ - известняки тапсинской свиты $\left(\epsilon_{1} t p\right) ; 3$ - осадочно-вулканогенные породы верхней подсвиты туматтайгинской свиты $\left(R-\epsilon_{1} t m_{2}\right)$ : квариевые порфиры и их туфы с прослояли доломитов; 4, 5 - раннетаннуольский габбро-диорит-плагиогранитный колплекс $\left(O_{1} t n\right): 4$ - плагиограниты $(\rho \gamma)$, тоналиты $(\gamma \delta) ; 5$ - квариевые диориты ( $\left.q \delta\right) ; 6$ - скарны; 7 рудные тела; 8 - геологические границы; 9 - разрывные нарушения; 10 - зоны дробления; 11 - контур месторождения Барсучий

Fig. 1. Geological scheme of Barsuchy deposit (after [3], modified): 1 - alluvium ( $\left.Q_{\mathrm{III-N}}\right) ; 2$ - limestones of the Tapsa Formation $\left(\epsilon_{1} t p\right) ; 3-$ sedimentary-volcanogenic rocks of the Upper Tumat-Taiga Subformation $\left(V-\epsilon_{1} t m_{2}\right)$ : quartz porphyries and tuffs interbedded by dolomites; 4, 5 -Earlier Tannuolsky diorite-tonalite-plagiogranite complex $\left(O_{1}\right.$ tn $): 4$ - plagiogranites $(\rho \gamma)$ and tonalites $(\gamma \delta) ; 5$ - quartz diorites (q $\delta$ ); 6 - skarns; 7 - ore bodies; 8 - geological boundaries; 9 - faults; 10 - crushing zones; 11 - Barsuchy deposit contour

\section{Последовательность минералообразования}

При детальных минералогических исследованиях руд в качестве критериев для установления последовательности минералообразования руд использовались онтогенические признаки (состав, строение минералов, индукционные поверхности), в том числе, пересечение минеральных агрегатов ранних стадий поздними, а также наличие обломков ранних минералов в минеральных агрегатах поздних стадий.

Штокверковая олото-сульфидно-кварцевая минерализация месторождения Барсучий развита в скарнах, роговиках, диоритах и осадочных поро- дах, которые осложнены тектоническими нарушениями. Скарны участка Барсучий сформировались на раннем этапе $(485,7 \pm 4,4$ млн лет) в экзоконтактовой части Копто-Байсютского массива с вулканогенно-осадочными породами туматтайгинской $\left(\mathrm{R}-\mathrm{C}_{1} t t\right)$ и тапсинской $\left(\mathrm{C}_{1} t p\right)$ свит [2]. $\mathrm{C}$ понижением температуры скарнового процесса формировались апоскарновые магнетит-амфиболовые метасоматиты и магнетитовые руды. Преобладающая часть руд с золотом приурочена к известковым магнетит-пироксеновым и гранат-пироксеновым (эпидот, кальцит) и, в меньшей степени, магнетитсерпентиновым магнезиальным скарнам. Магне- 
зиальные скарны на месторождении Барсучий распространены ограниченно относительно известковых. На первичные парагенезисы магнезиальных и известковых скарнов накладываются более поздние постскарновые процессы, обусловившие значительное изменение скарнов вплоть до полного их преобразования в серпентин-карбонатные, актинолитовые, серпентин-актинолит-карбонатные породы.

Окварцевание и гематитизация выражены в наличии тонкодисперсной рассеянной вкрапленности гематита в кварцитах, часто замещающего магнетит. Амфиболизация и хлоритизация выражены в преобразовании пироксенов и амфиболов скарнов вплоть до полного их замещения. Среди пород участка подобные изменения установлены в небольших объёмах. Серпентинизация проявлена широко и затрагивает в той или иной степени скарны, диориты и карбонатные породы. Серпентин замещает пироксены, амфиболы, хлорит и оливин. Апоскарновые изменения (серпентинизация, ам- фиболизация, хлоритизация, окварцевание с ожелезнением) на месторождении часто совмещены друг с другом. Зоны измененных пород образуют линейные и линзовидные тела в скарнах и несут прожилково-вкрапленную продуктивную минерализацию золота.

Магнетитовые руды образуют массивные, прожилковые, прожилково-вкрапленные и шлировые тела мощностью от 5 см и более 1,5 м. Структуры руд - гипидиоморфная, коррозионная. Кристаллы и зёрна магнетита скарнов и магнетитовых руд рассечены и цементируются сульфидно-кварцевыми прожилками продуктивных стадий. Мы предполагаем, что образования более раннего этапа генетически связаны с магнетит-скарновой формацией, а с гидротермальной золоторудной минерализацией связаны лишь пространственно.

Собственно гидротермальный золоторудный этап сопровождается интенсивным тектоническим дроблением скарнов и апоскарновых метасоматитов. На месторождении Барсучий наложенное на

таблица 1. Схема последовательности минералообразования месторождения Барсучий

Table 1. Sequence of mineral formation in Barsuchy deposit

\begin{tabular}{|c|c|c|c|c|c|}
\hline $\begin{array}{l}\text { Этапы } \\
\text { Stages }\end{array}$ & Гидроте & $\begin{array}{l}\text { мальный золот } \\
\text { Hydrothermal gc }\end{array}$ & $\begin{array}{l}\text { o-cульфидно-кв } \\
\text { old-sulfide-quartz }\end{array}$ & ррцевый & \\
\hline 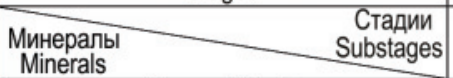 & 1 & 2 & 3 & 4 & $\begin{array}{l}\text { 1 ипергенныи } \\
\text { Supergene }\end{array}$ \\
\hline Кварц / Quartz & & & & 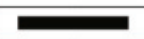 & \\
\hline Кальцит / Calcite & & & & & \\
\hline Доломит / Dolomite & - & & & & \\
\hline Сидерит / Siderite & - & & - & & \\
\hline Анкерит / Ankerite & - & & & & \\
\hline Мусковит / Muscovite & - & & & & \\
\hline Фуксит / Fuchsite & - & & & & \\
\hline Пирит / Pyrite & 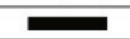 & 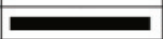 & 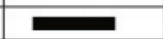 & & \\
\hline Пирротин / Pyrrhotite & & - & - & & \\
\hline Халькопирит / Chalcopyrite & & a & 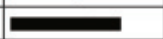 & & \\
\hline Арсенопирит / Arsenopyrite & & - & & & \\
\hline Марказит / Marcasite & & - & & & \\
\hline Галенит / Galena & & & - & & \\
\hline Теллуровисмутит / Tellurobismuthite & & & - & & \\
\hline Sb-теллуровисмутит / Se-tellurobismuthite & & & & & \\
\hline Ві-теллурантимон / Bi-tellurantimony & & & $\longrightarrow$ & & \\
\hline Теллурантимон / Tellurantimony & & & 一 & & \\
\hline Сфалерит / Sphalerite & & & - & & \\
\hline Золото / Native gold & & - & 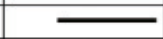 & & \\
\hline Калаверит / Calaverite & & & - & & \\
\hline $\begin{array}{c}\text { Твёрдый раствор }(\mathrm{Au}, \mathrm{Ag})_{2} \mathrm{Te} \\
\text { Solid solution }(\mathrm{Au}, \mathrm{Ag})_{2} \mathrm{Te}\end{array}$ & & & - & & \\
\hline Петцит / Petzite & & & - & & \\
\hline Гессит / Hessite & & & - & & \\
\hline Кобальтин / Cobaltite & & & - & & \\
\hline Хлорит / Chlorite & & & & & \\
\hline Ковеллин / Covellite & & & & & \\
\hline Халькозин / Chalcocite & & & & & \\
\hline Гематит / Hematite & & & & & \\
\hline Дигенит / Digenite & & & & & - \\
\hline Малахит / Malachite & & & & & \\
\hline Азурит / Azurite & & & & & $\longrightarrow$ \\
\hline Гётит / Goethite & & & & & \\
\hline Церуссит / Cerussite & & & & & $\longrightarrow$ \\
\hline
\end{tabular}

Прилечание. Толщина линий указывает на относительную степень распространённости минерала.

Note. The line thickness marks the relative abundance of mineral. 
скарны, роговики, диориты и апоскарновые метасоматиты золото-сульфидно-кварцевое оруденение образовалось в течение 4 стадий: 1) дорудная лиственитовая; 2) I продуктивная золото-пирротинхалькопирит-пирит-кварцевая; 3) II продуктивная золото-теллуридно-пирротин-халькопиритпирит-кварцевая; 4) пострудная кальцит-кварцхлоритовая. В коре выветривания развиты лимонит, гетит и другие минералы (табл. 1).

Околорудные процессы выражены в березитизации и лиственитизации диоритов, скарнов, осадочно-вулканогенных пород туматтайгинской $\left(\mathrm{R}-\mathrm{G}_{1} t t\right)$ и тапсинской $\left(\mathrm{G}_{1} t p\right)$ свит, которые проявлены в виде небольших зон (3-40 cм).

Золоторудная минерализация. Золотопродуктивные минеральные ассоциации образуют мелкие гнёзда, вкрапленную и прожилково-вкрапленную, реже жильную минерализацию в скарнах, апоскарновых метасоматитах и кварцевых диоритах (рис. 3). Содержание сульфидов в рудах варьирует от 1 до $5 \%$ и составляет, в среднем, $3 \%$. По классам крупности в рудах количественно преобладает золото меньше $0,1 \mathrm{~mm} \quad(40,65 \%), \quad 0,2-0,1$ $(24,55 \%)$ и 0,5-0,2 мм $(22,85 \%)$, и, в меньшей степени, встречаются зерна размером $1-0,5$ мм $(8,6 \%), 2-1$ мм $(3,35 \%)$.
I продуктивная золото-пирротин-халькопиритпирит-кварцевая стадия отмечается в виде гнёзд (до $1,5 \mathrm{~cm}$ ) и прожилков (до $2 \mathrm{~cm}$ ), а также жил мощностью от 0,10 до 0,25 м и протяженностью от 4 до 15 м. Простирание жил и жильно-прожилковых зон субмеридиональное (рис. 2). Они сложены мелкозернистым, серым и полупрозрачным кварцем с вкрапленниками, гнёздами пирита и халькопирита. Минеральная ассоциация I продуктивной стадии цементирует более ранние минеральные ассоциации скарнов и апоскарновых метасоматитов с магнетитом, гранатом и амфиболом.

Золото (размером до 1,6 мм) образует срастания с пиритом, халькопиритом, пирротином и самостоятельные зёрна в кварце, а также развивается по трещинам породообразующих минералов скарнов и апоскарновых пород. Для золота характерны интерстициальные (чешуйки, комковидные частицы), цементационные (комковидно-ветвистые, ячеистые, петельчатые) формы, а также идиоморфные кристаллы с развитием комбинации форм куба и октаэдра и их срастаниями (рис. 3).

Цвет золотисто-жёлтый, и по содержанию $\mathrm{Ag}$ оно представлено:

1) весьма высокопробным золотом ( $\mathrm{Au} 94,23-96,99$; $\operatorname{Ag} 2,76-4,94 ; \mathrm{Cu} 0,00-0,04)$
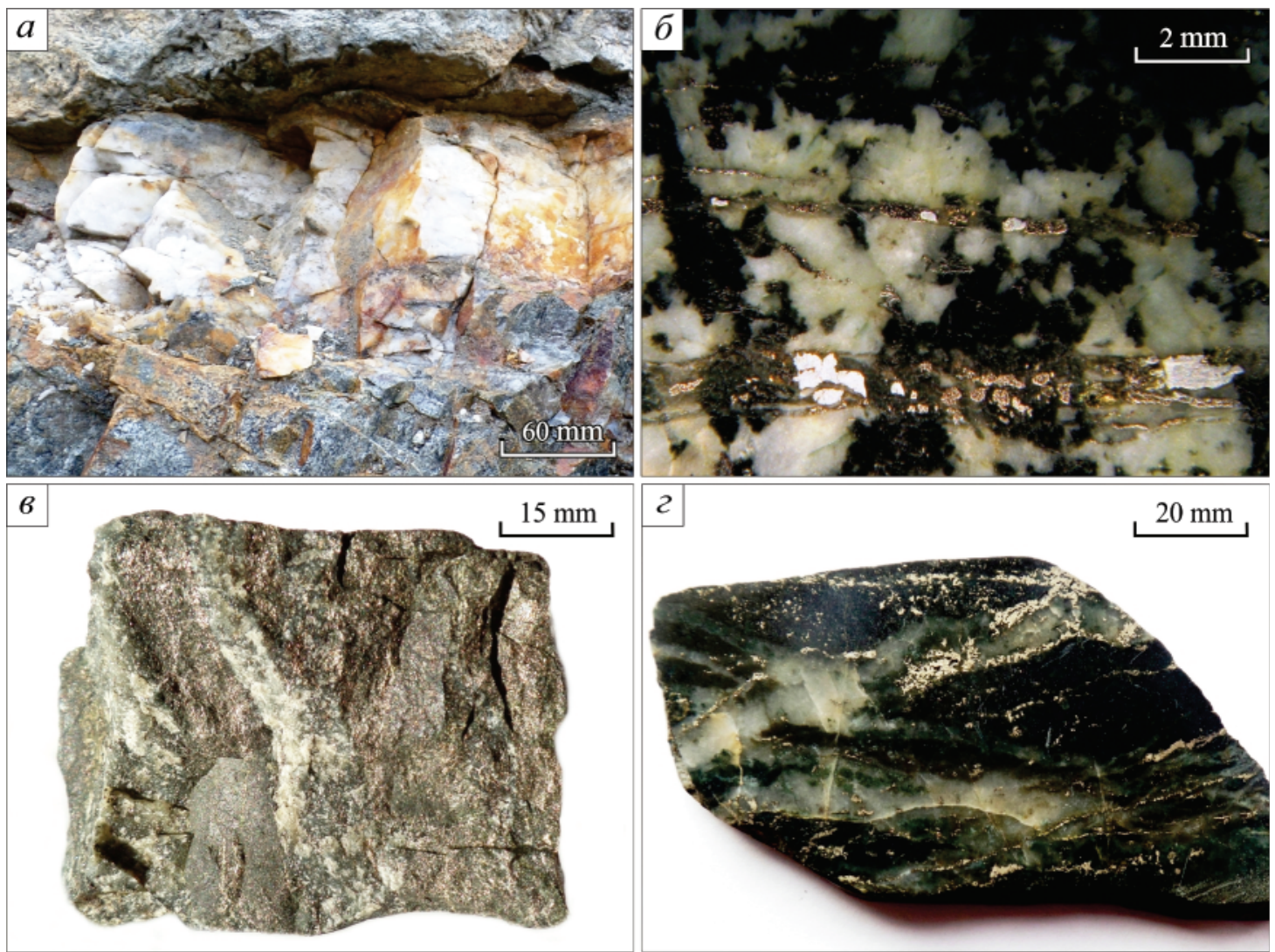

Рис. 2. Сульфидно-кварцевые жилы и прожилки I продуктивной стадии в кварцевых диоритах (а, б) и прожилково-вкрапленная минерализаиия II продуктивной стадии в магнетитовых рудах (в) и алфиболовых метасоматитах (2)

Fig. 2. Sulfide-quartz veins and veinlets of I Au-bearing substage in quartz diorites ( $a, \sigma)$ and vein-disseminated mineralization of the II Aubearing substage in magnetite ores ( 8 ) and amphibole metasomatites (2) 

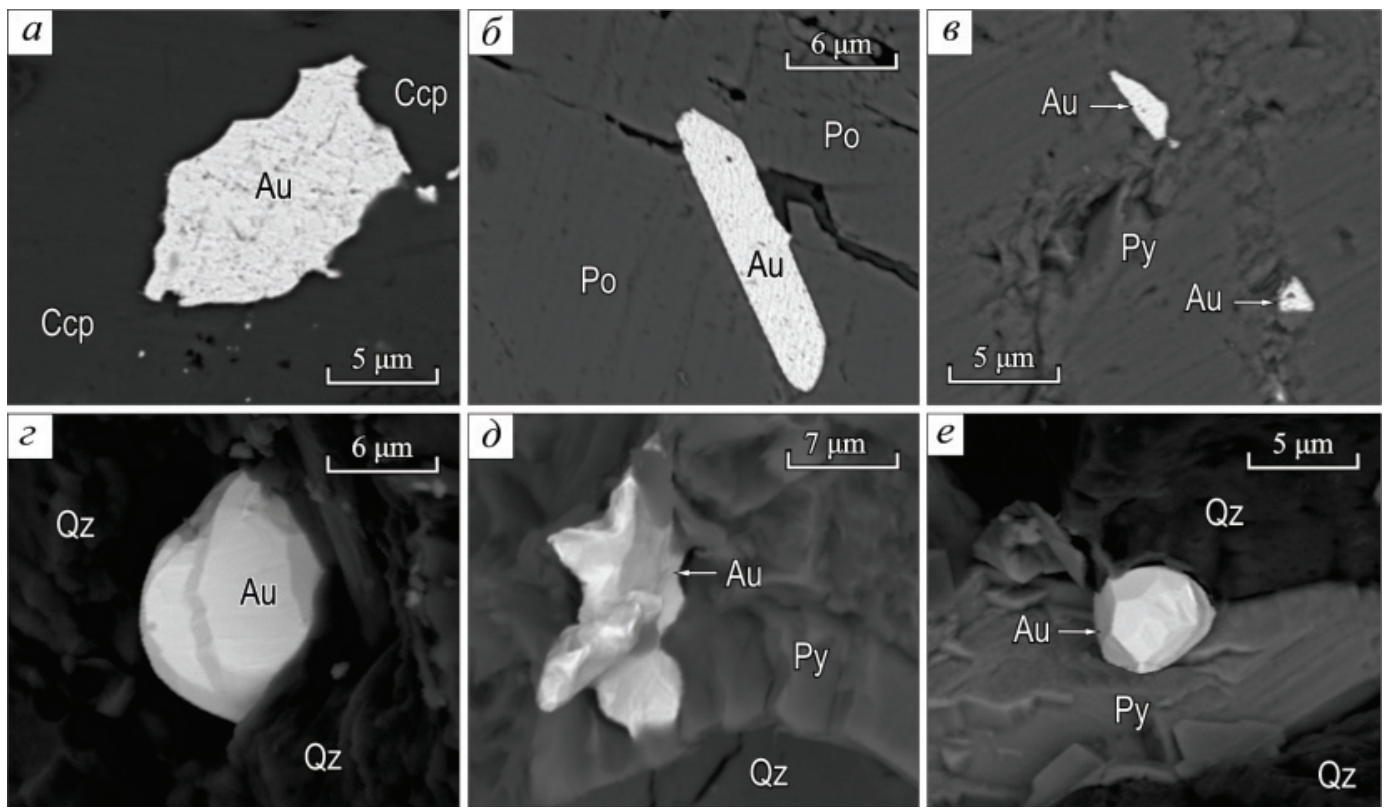

Рис. 3. Формы выделения золота золото-пирротин-халькопирит-пирит-квариевой (I продуктивной) стадии. Qz - квари, Аи - золото, Ру - пирит, Ро - пирротин, Сср - халькопирит. Изображение в обратно рассеянных электронах

Fig. 3. Morphology of gold and associated gold-pyrrhotite-chalcopyrite-pyrite-quartz (I Au-bearing substage) minerals: Qz-quartz, Au - gold, Py-pyrite, Po-pyrrhotite, Ccp-chalcopyrite. BSE image
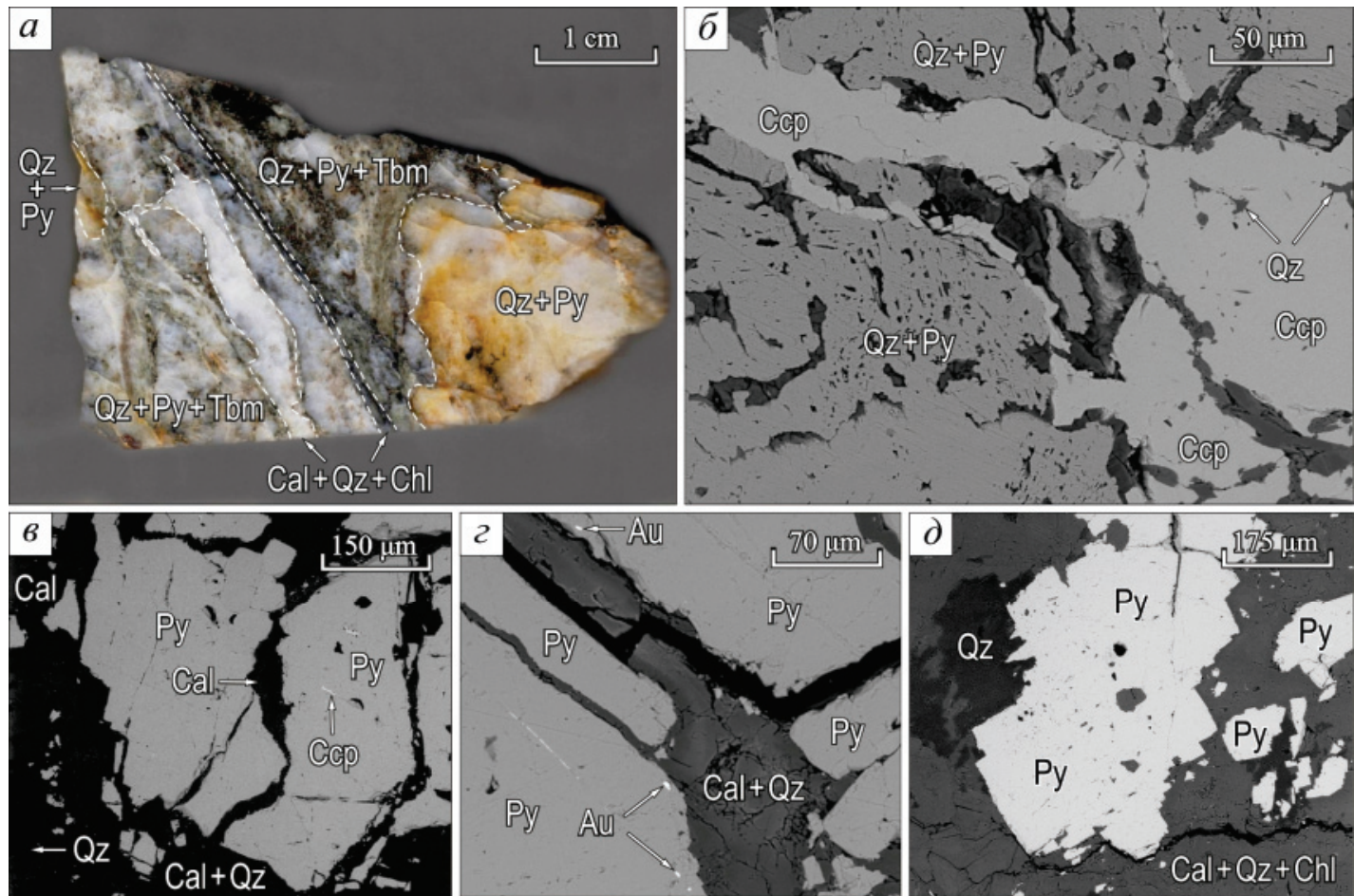

Pис.4. Минеральные ассоииации месторождения Барсучий: а) брекчированные пирит-квариевые (Qz+Pу) агрегаты I продуктивной стадии и секущие пострудные кальиит-квари-хлоритовые (Cal+Qz+Chl) прожилки в минеральных агрегатах II продуктивной стадии с кварием (Qz), пиритом (Рy) и теллуровисмутитом (Tbm); б) иементация пирит-квариевых (Qz+Ру) агрегатов I продуктивной стадии квари-халькопиритовыми (Qz+Ccp) агрегатами II продуктивной стадии; в-д) пересечение и иементация минеральных агрегатов I продуктивной стадии $(Q z, P y, C c p, A u)$ с пострудныли кальиит-квариевыми $(C a l+Q z)$ и кальиит-квари-хлоритовыли (Cal+Qz+Chl) прожилками. $a-$ рото, б-d - изображения в обратно рассеянных электронах

Fig. 4. Mineral assemblages of Barsuchy deposit: a) brecciated pyrite-quartz (Qz+Py) aggregates of I Au-bearing substage and cutting-through post-ore calcite-quartz-chlorite (Cal $+Q z+C h l)$ veinlets in mineral aggregates of II Au-bearing substage with quartz (Qz), pyrite (Py) and tellurobismuthite (Tbm); б) cementation of pyrite-quartz (Qz+Py) aggregates of I Au-bearing substage with quartz-chalcopyrite $(Q z+C c p)$ aggregates of II Au-bearing substage; $\left.b^{-}-\partial\right)$ intersection and cementation of minerals of I Au-bearing substage (Qz, Py, Ccp, $\mathrm{Au})$ with calcite-quartz $(\mathrm{Cal}+\mathrm{Qz})$ and calcite-quartz-chlorite) $(\mathrm{Cal}+Q z+C h l)$ veinlets. $a-$ photo, $\sigma-\partial-B S E$ image 


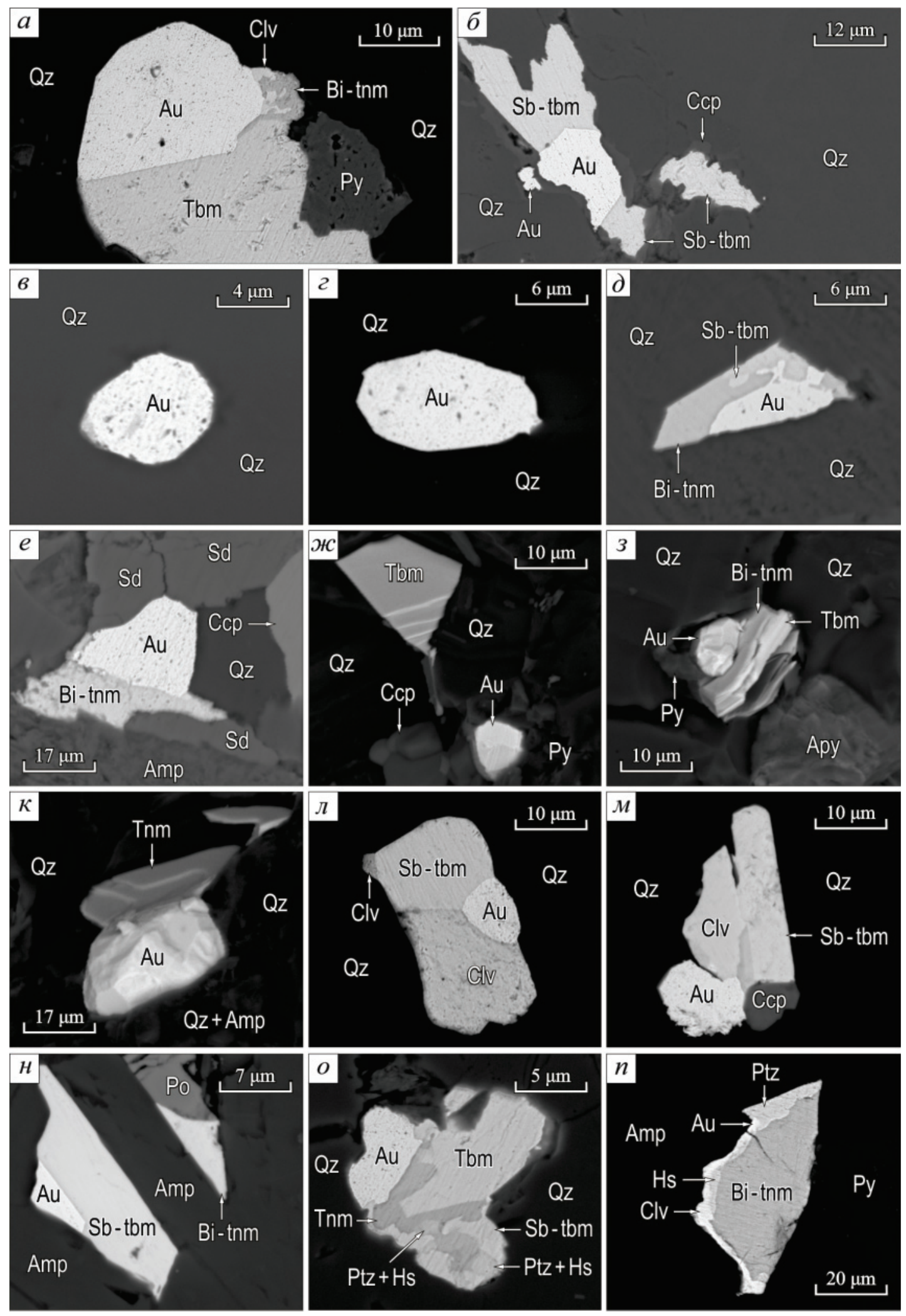

Рис. 5. Формы выделения золота и сосуществующих минералов золото-теллуридно-пирротин-халькопирит-пирит-квариевой (II продуктивной) стадии. Tbm - теллуровисмутит, Sb-tbm - Sb-теллуровисмутит, Tnm - теллурантимон, Bi-tnт - Bi-mеллурантилон, Py - пирит, Clv - калаверит, Au - золото, Ptz - петиит, $\mathrm{Hs}$ - гессит, Сср - халькопирит, Ару - арсенопирит, Qz квари, Sd - сидерит, Атр - алфибол. Изображение в обратно рассеянных электронах

Fig. 5. Morphology of gold and associated gold-telluride-pyrrhotite-chalcopyrite-pyrite-quartz (II Au-bearing substage). Minerals: Tbm - tellurobismuthite, Sb-tbm - Sb-tellurovismutite, Tnm - tellurantimony, Bi-tnm-Bi-tellurantimony, Py - pyrite, Clv - calaverite, Au - gold, Ptz - petzite, $H s$ - hessite, Ccp - chalcopyrite, Apy - arsenopyrite, Qz - quartz, Sd - siderite, Am - amphibole. BSE image 
2) высокопробным золотом (Au 93,16-94,72; Ag 4,84-6,40; $\mathrm{Cu} 0,00-0,09$ ).

Золото этой стадии тесно ассоциирует с пиритом, халькопиритом, пирротином и характеризуется вариациями пробности от 950 до $972 \%$ (в среднем, $958 \%$ ).

Золото-теллуридно-пирротин-халькопирит-пирит-кварцевая (II продуктивная) стадия с халькопиритом, пиритом, галенитом, арсенопиритом, калаверитом, петцитом, гесситом, сфалеритом, неограниченными твёрдыми растворами минералов ряда теллуровисмутит-теллурантимонит, редкими выделениями кобальтина и Со-содержащего арсенопирита (Со до 4 мас. \%) отмечается в виде сульфидно-кварцевых гнёзд (размером до 0,5 мм) и прожилков (мощностью до 5 см) в магнетитовых рудах, актинолитовых метасоматитах и жилах I продуктивной стадии, цементируя брекчированные минеральными агрегатами предыдущих стадий $(4, a, \sigma)$

Сульфидная минерализация представлена пиритом, халькопиритом и пирротином, остальные минералы развиты в небольших количествах. Кварц в прожилках и гнёздах мелкозернистый, серый, полупрозрачный, реже прозрачный. Характерной особенностью данной стадии являются многочисленные закономерные срастания минералов ряда теллуровисмутит-теллурантимон и ассоциирующие с ними золото и калаверит (рис. 6).

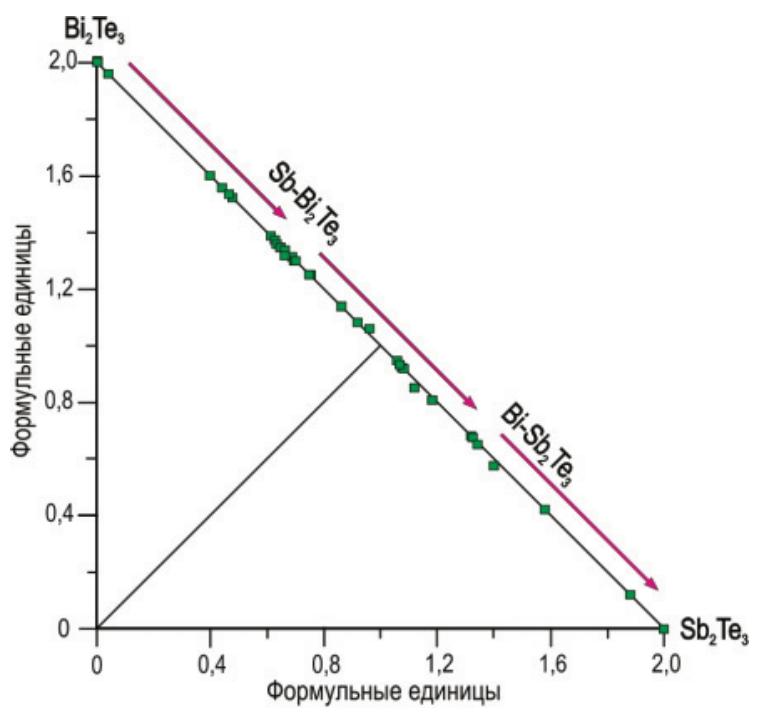

Puc. 6. Соотношение Bi u Sb (ф.е.) в минералах ряда теллуровис мутит-теллурантилон. Стрелкой показана эволюиия состава от теллуровисмутита к теллурантимону

Fig. 6. Bi/Sb ratio (f.u.) in minerals of the tellurobismuthite-tellurantimony series. The arrow shows the evolution of the com position from tellurovismutite to tellurantimon

Таблитчатые кристаллы с выраженной спайностью минералов ряда теллуровисмутит-теллурантимон образуют срастания. Sb-теллуровисмутит, Ві-теллурантимон и теллурантимон развиваются, как правило, по периферии зёрен теллуровисмутита (рис. 5 ж, з). На рис. 6 представлен тренд эво- люции состава теллуровисмутита к теллурантимону через $\mathrm{Sb}$-содержащий теллуровисмутит (Sb от 0,58 до 16,09 мас. \% ) и Вi-содержащий теллурантимон (Ві от 3,84 до 27,95 мас. \% ) (табл. 2).

Таблица 2. Химический состав минералов ряда теллуровисмутит-теллурантимон (мас.\%)

Table 2. Chemical composition of minerals of tellurobismuthitetellurantimony series (wt.\%)

\begin{tabular}{|c|c|c|c|c|c|}
\hline \begin{tabular}{c|} 
Анализ \\
Analysis
\end{tabular} & $\mathrm{Bi}$ & $\mathrm{Sb}$ & $\mathrm{Te}$ & $\begin{array}{c}\text { Сумма } \\
\text { Total }\end{array}$ & $\begin{array}{l}\text { Формула } \\
\text { Formula }\end{array}$ \\
\hline 1 & 52,27 & - & 47,43 & 99,70 & $\mathrm{Bi}_{2,01} \mathrm{Te}_{2,99}$ \\
\hline 2 & 52,45 & - & 47,25 & 99,70 & $\mathrm{Bi}_{2,02} \mathrm{Te}_{2,98}$ \\
\hline 3 & 51,61 & - & 48,19 & 99,80 & $\mathrm{Bi}_{1,98} \mathrm{Te}_{3,02}$ \\
\hline 4 & 51,42 & 0,58 & 47,75 & 99,75 & $\left(\mathrm{Bi}_{1,97} \mathrm{Sb}_{0,04}\right)_{2,01} \mathrm{Te}_{2,99}$ \\
\hline 5 & 42,77 & 6,79 & 50,43 & 99,99 & $\left(\mathrm{Bi}_{1,56} \mathrm{Sb}_{0,43}\right)_{1,99} \mathrm{Te}_{3,01}$ \\
\hline 6 & 41,87 & 7,64 & 50,12 & 99,63 & $\left(\mathrm{Bi}_{1,53} \mathrm{Sb}_{0,48}\right)_{2,01} \mathrm{Te}_{2,99}$ \\
\hline 7 & 38,80 & 9,90 & 51,20 & 99,90 & $\left(\mathrm{Bi}_{1,39} \mathrm{Sb}_{0,61}\right)_{2,00} \mathrm{Te}_{3,00}$ \\
\hline 8 & 38,68 & 10,18 & 51,08 & 99,94 & $\left(\mathrm{Bi}_{1,38} \mathrm{Sb}_{0,63}\right)_{2,01} \mathrm{Te}_{2,99}$ \\
\hline 9 & 38,23 & 10,32 & 51,44 & $\begin{array}{l}9,99 \\
\end{array}$ & $\left(\mathrm{Bi}_{1,36} \mathrm{Sb}_{0,63}\right)_{1,99} \mathrm{Te}_{3,01}$ \\
\hline 10 & 37,94 & 10,53 & 51,53 & 100 & $\left(\mathrm{Bi}_{1,35} \mathrm{Sb}_{0,64}\right)_{1,99} \mathrm{Te}_{3,01}$ \\
\hline 11 & 37,25 & 10,81 & 51,9 & 99,96 & $\left(\mathrm{Bi}_{1,33} \mathrm{Sb}_{0,66}\right)_{1,99} \mathrm{Te}_{3,01}$ \\
\hline 12 & 37,35 & 10,82 & 51,75 & 99,92 & $\left(\mathrm{Bi}_{1,33} \mathrm{Sb}_{0,66}\right)_{2,01} \mathrm{Te}_{3,01}$ \\
\hline 13 & 37,12 & 11,27 & 51,62 & 100,01 & $\left(\mathrm{Bi}_{1,32} \mathrm{Sb}_{0,68}\right)_{2,00} \mathrm{Te}_{3,00}$ \\
\hline 14 & 36,99 & 10,79 & 52,14 & 99,92 & $\left(\mathrm{Bi}_{1,31} \mathrm{Sb}_{0,66}\right)_{1,97} \mathrm{Te}_{3,03}$ \\
\hline 15 & 36,71 & 11,27 & 51,86 & 99,84 & $\left(\mathrm{Bi}_{1,30} \mathrm{Sb}_{0,68}\right)_{1,99} \mathrm{Te}_{3,01}$ \\
\hline 16 & 36,41 & 11,39 & 51,59 & 99,39 & $\left(\mathrm{Bi}_{1,30} \mathrm{Sb}_{0,69}\right)_{1,99} \mathrm{Te}_{3,01}$ \\
\hline 17 & 35,62 & 12,32 & 51,94 & 99,88 & $\left(\mathrm{Bi}_{1,25} \mathrm{Sb}_{0,75}\right)_{2,00} \mathrm{Te}_{3,00}$ \\
\hline 18 & 35,63 & 12,17 & 52,19 & 99,99 & $\left(\mathrm{Bi}_{1,25} \mathrm{Sb}_{0,74}\right)_{1,99} \mathrm{Te}_{3,01}$ \\
\hline 19 & 32,56 & 14,24 & 52,35 & 99,15 & $\left(\mathrm{Bi}_{1,14} \mathrm{Sb}_{0,86}\right)_{2,00} \mathrm{Te}_{3,00}$ \\
\hline 20 & 31,18 & 15,54 & 52,82 & 99,54 & $\left(\mathrm{Bi}_{1,08} \mathrm{Sb}_{0,92}\right)_{2,00} \mathrm{Te}_{3,00}$ \\
\hline 21 & 30,79 & 16,09 & 52,27 & 99,15 & $\left(\mathrm{Bi}_{1,07} \mathrm{Sb}_{0,96}\right)_{2,03} \mathrm{Te}_{2,97}$ \\
\hline 22 & 27,95 & 18,14 & 53,74 & 99,83 & $\left(\mathrm{Sb}_{1,06} \mathrm{Bi}_{0,95}\right)_{2,01} \mathrm{Te}_{2,99}$ \\
\hline 23 & 27,18 & 18,27 & 54,56 & 100.01 & $\left(\mathrm{Sb}_{1,06} \mathrm{Bi}_{0,92}\right)_{1,98} \mathrm{Te}_{3,02}$ \\
\hline 24 & 27,42 & 18,37 & 54,21 & 100 & $\left(\mathrm{Sb}_{1,07} \mathrm{Bi}_{0,93}\right)_{2,00} \mathrm{Te}_{3,00}$ \\
\hline 25 & 25,37 & 19,36 & 55,27 & 100 & $\left(\mathrm{Sb}_{1,11} \mathrm{Bi}_{0,85}\right)_{1,96} \mathrm{Te}_{3,04}$ \\
\hline 26 & 24,30 & 20,60 & 55,11 & 100,1 & $\left(\mathrm{Sb}_{1,18} \mathrm{Bi}_{0,81}\right)_{1,99} \mathrm{Te}_{3,01}$ \\
\hline 27 & 20,47 & 23,27 & 55,76 & 99,50 & $\left(\mathrm{Sb}_{1,32} \mathrm{Bi}_{0,67}\right)_{1,99} \mathrm{Te}_{3,01}$ \\
\hline 28 & 20,42 & 23,56 & 55,57 & 99,55 & $\left(\mathrm{Sb}_{1,33} \mathrm{Bi}_{0,67}\right)_{2,00} \mathrm{Te}_{3,00}$ \\
\hline 29 & 20,01 & 23,84 & 56,07 & 99,92 & $\left(\mathrm{Sb}_{1,34} \mathrm{Bi}_{0,65}\right)_{1,99} \mathrm{Te}_{3,01}$ \\
\hline 30 & 17,62 & 25,18 & 57,15 & 99,95 & $\left(\mathrm{Sb}_{1,40} \mathrm{Bi}_{0,57}\right)_{1,97} \mathrm{Te}_{3,03}$ \\
\hline 31 & 14,74 & 27,97 & 57,21 & 99,92 & $\left(\mathrm{Sb}_{1,53} \mathrm{Bi}_{0,47}\right)_{2,00} \mathrm{Te}_{3,00}$ \\
\hline 32 & 13,39 & 29,10 & 57,25 & 99,74 & $\left(\mathrm{Sb}_{1,59} \mathrm{Bi}_{0,43}\right)_{2,02} \mathrm{Te}_{2,98}$ \\
\hline 33 & 3,84 & 35,76 & 60,23 & 99,83 & $\left(\mathrm{Sb}_{1,87} \mathrm{Bi}_{0,12}\right)_{1,99} \mathrm{Te}_{3,01}$ \\
\hline 34 & - & 39,01 & 60,87 & 99,88 & $\mathrm{Sb}_{2,01} \mathrm{Te}_{2,99}$ \\
\hline
\end{tabular}

Примечание. 1-4-теллуровисмутит, 5-21- Sb-содержаший теллуровисмутит, 22-33- Ві-содержащий теллурантилон, $34-$ теллурантимон. Формулы минералов ряда теллуровисмутит-теллурантимон рассчитаны на 5 атомов.

Note. 1-4 - tellurobismuthite, 5-21 - Sb-bearing tellurobismuthite, 22-33-Bi-bearing tellurantimony, 34 - tellurantimony. The formula of minerals of tellurobismuthite-tellurantimony series are calculated for 5 atoms.

Золото (до 0,9 мм) II продуктивной стадии часто образует срастания с минералами ряда теллуровисмутит-теллурантимон, пиритом, халькопиритом, калаверитом, реже- гесситом и петцитом. Для золота характерны интерстициальные, цементационные трещинно-прожилковые, дендритовидные, гемиидиоморфные и идиоморфные (кристаллы с комбинацией куба и октаэдра) формы (рис. 5). 
Цвет золотисто-жёлтый, реже светло-жёлтый. Золото по содержанию $\mathrm{Ag}$ представлено:

1) высокопробным золотом (Au 89,46-92,94; Ag 6,73-9,84);

2) среднепробным золотом (Au 79,94-89,40; $\mathrm{Ag}$ 10,55-19,76);

3) низкопробным золотом (Au 78,06-79,29; Ag 20,41-21,92).

Средняя пробность золотин II продуктивной стадии составляет $863 \%$ (781-932\%o).

Калаверит $\mathrm{AuTe}$ встречается исключительно в кварце в срастаниях с золотом (902-932 \%о), теллуровисмутитом, $\mathrm{Sb}$-теллуровисмутитом или образует самостоятельные зёрна в кварце. В ассоциации с калаверитом отмечаются срастания петцита и гессита с высокопробным золотом (рис. $3,0, n)$. Эти необычные петцит-гесситовые срастания могли возникнуть при распаде твёрдого раствора $(\mathrm{Au}, \mathrm{Ag})_{2} \mathrm{Te}$, т. к. высокая пробность золота (более 920 \%о) приводит к невозможности его совместного нахождения с гесситом и петцитом [8]. Химические составы теллуридов $\mathrm{Au}$ и $\mathrm{Ag}$ показаны в табл. 3.

Таблица 3. Химический состав калаверита, петцита и гессита (mac. \%)

Table 3. Chemical composition of calaverite, petzite and hessite (wt. \%)

\begin{tabular}{|c|c|c|c|c|c|c|}
\hline $\begin{array}{c}\text { Анализ } \\
\text { Analysis }\end{array}$ & $\mathrm{Au}$ & $\mathrm{Ag}$ & $\mathrm{Te}$ & $\mathrm{Se}$ & $\begin{array}{c}\text { Cyмma } \\
\text { Total }\end{array}$ & $\begin{array}{c}\text { Формула } \\
\text { Formula }\end{array}$ \\
\hline \multicolumn{7}{|c|}{ Калаверит/Calaverite } \\
\hline 1 & 42,97 & - & 56,09 & - & 99,06 & $\mathrm{Au}_{1,00} \mathrm{Te}_{2,00}$ \\
\hline 2 & 43,25 & - & 56,25 & - & 99,50 & $\mathrm{Au}_{1,00} \mathrm{Te}_{2,00}$ \\
\hline 3 & 44,17 & - & 55,32 & - & 99,49 & $\mathrm{Au}_{1,02} \mathrm{Te}_{1,98}$ \\
\hline \multicolumn{7}{|c|}{ Петииm/Petzite } \\
\hline 4 & 25,82 & 41,3 & 32,29 & - & 99,41 & $\mathrm{Ag}_{3,00} \mathrm{Au}_{1,02} \mathrm{Te}_{1,98}$ \\
\hline 5 & 25,14 & 41,34 & 32,98 & - & 99,46 & $\mathrm{Ag}_{2,99} \mathrm{Au}_{1,00} \mathrm{Te}_{2,01}$ \\
\hline \multicolumn{7}{|c|}{ Гeccum/Hessite } \\
\hline 6 & - & 62,69 & 36,92 & - & 99,61 & $\mathrm{Ag}_{2,00} \mathrm{Te}_{1,00}$ \\
\hline 7 & - & 63,67 & 36,11 & - & 99,78 & $\mathrm{Ag}_{2,03} \mathrm{Te}_{0,97}$ \\
\hline
\end{tabular}

Примечание. Форлула калаверита рассчитана на 3 атома, пет иита - на 6 атомов, гессита - на 3 атома.

Note. The formula of calaverite is calculated for 3 atoms, petzit - for 6 atoms, hessite - for 3 atoms.

Для зёрен золота продуктивных стадий характерна стандартная зональность, представленная увеличением содержания $\mathrm{Ag}$ от центра зерна к периферии при уменьшении содержания Au: для 30лота I продуктивной стадии наблюдается увеличение содержания $\mathrm{Ag}$ к периферии зёрен до 1 мас. \%, для II продуктивной стадии - Ag до 3,5 мас. \%. Изменение состава самородного золота I продуктивной стадии следующее: весьма высокопробное золото (Ag до 4,9 мас. \% ) $\rightarrow$ высокопробное золото (Ag до 6,4 мас. \% ); II продуктивной стадии- высокопробное золото (Ag до 10 мас. \%) $\rightarrow$ среднепробное золото (Ag до 19 мас. \% ) \pm калаверит \pm твёрдый раствор $(\mathrm{Au}, \mathrm{Ag})_{2} \mathrm{Te}+$ петцит + гессит $\rightarrow$ среднепробное золото $(\mathrm{Ag}$ до 20 мас. \% $) \rightarrow$ низкопробное золото ( $\mathrm{Ag}$ до 22 мас. \%).

На месторождении Барсучий средняя пробность золота составляет $904 \%$ (95 ан.) при вариа- циях от 781 до $972 \%$. При этом средняя пробность золотин I продуктивной стадии составляет $958 \%$ (950-972\%o), II продуктивной стадии $863 \%$ (781-932 \%о). Составы золота продуктивных стадий месторождения образуют бимодальное распределение, и в рудах преобладает весьма высокопробное и среднепробное золото (рис. 7).

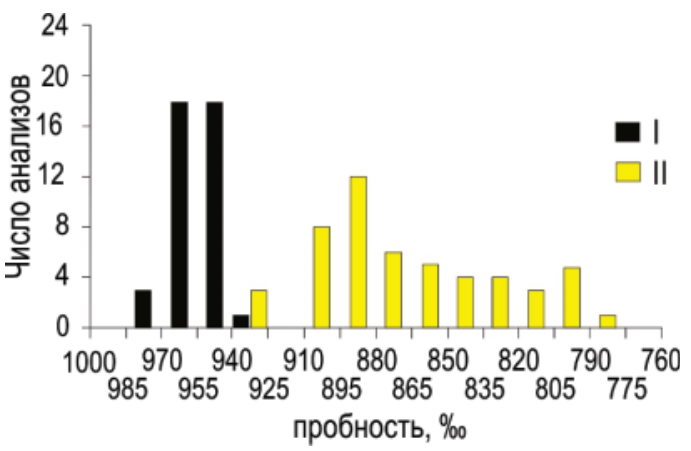

Pис. 7. Частота встречаемости самородного золота по пробности I и II продуктивных стадий

Fig. 7. Frequency of native gold according to probabilities of I and II Au-bearing substages

\section{Условия образования руд}

В кварце I продуктивной стадии месторождения диагностированы первичные и псевдовторичные флюидные включения, согласно классификации Э. Реддера [9], их можно разделить по фазовому составу на следующие генерации: 1) двухфазные газово-жидкие (VL); 2) трехфазные газовожидкие с твёрдой фазой (VLS).

Первичные VL включения встречаются в виде одиночных вакуолей изометричной формы (иногда с выраженными кристаллографическими гранями) размерами 4-10 мкм (рис. 8).

Доля газовой фазы, которая представлена углекислотой и метаном, составляет до 30 об. \% . Полученные температуры эвтектики $-25 . . .-19{ }^{\circ} \mathrm{C}$ предполагают присутствие в растворе хлоридов $\mathrm{K}$ и $\mathrm{Na}$. Концентрация солей оценена по температурам плавления льда $-7 . . .-4,6{ }^{\circ} \mathrm{C}$ и составляет $7,3-10,5$ мас. $\%$

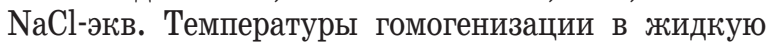
фазу установлены в интервале $360-340{ }^{\circ} \mathrm{C}$ (рис. $8, a$ ). Флюидные VLS включения (рис. 8, б) содержат тёмную минеральную фазу, которую не удалось идентифицировать ввиду малых размеров.

Псевдовторичные VL включения маркируют трещины, располагающиеся в пределах зерна кварца, имеют удлинённую форму и размеры до 12 мкм. Среди них встречаются включения, газовая фаза которых составляет до 60 об. \% и представлена смесью углекислоты и метана (рис. 8, в). Для псевдовторичных VL включений получены температуры плавления льда от $-1,5$ до $-0,8^{\circ} \mathrm{C}$, которым соответствуют концентрации солей 1,4-2,6 мас. \% NaCl-экв. Температуры гомогенизации составили $310-280{ }^{\circ} \mathrm{C}$.

В кварце II продуктивной стадии диагностированы первичные VL включения (с долей газовой 

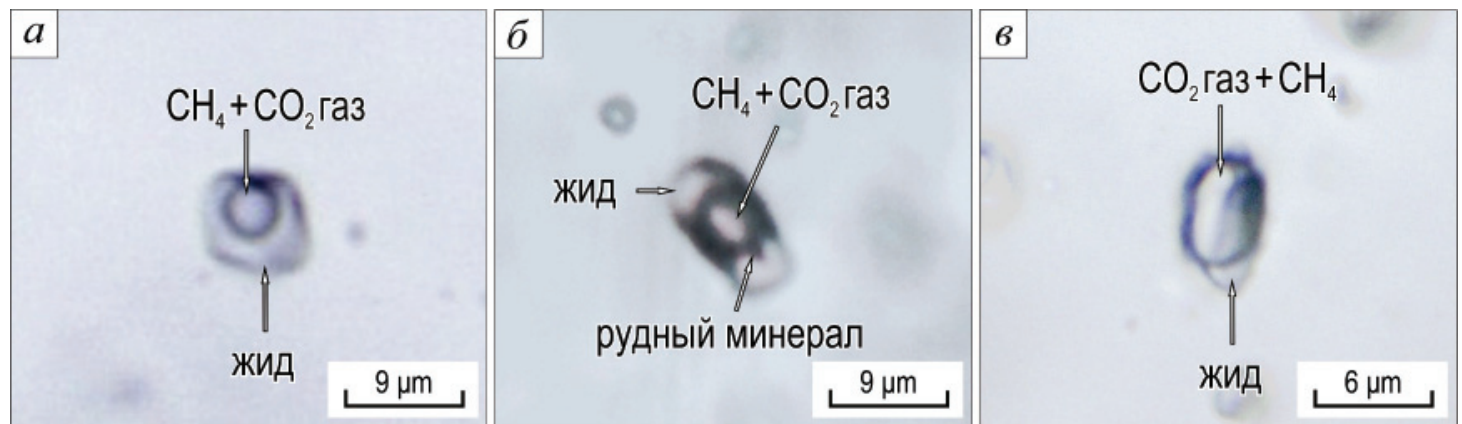

Pис. 8. Флюидные включения в кварие I продуктивной стадии: а, в-двухфазные VL; б- трехфазные VLS

Fig. 8. Fluid inclusions in quartz of I Au-bearing substage: a, в-two-phased VL; $\sigma$-three-phased VLS

вакуоли 15-20 об. \%), которые встречаются преимущественно в центральных частях зёрен. Они имеют изометричную форму и размеры 10-20 мкм. Температуры гомогенизации (в жидкую фазу) образуют интервал $320-240{ }^{\circ} \mathrm{C}$; концентрации растворов, согласно температурам плавления льда $\mathrm{T}_{\text {пा }}$ от $-5,7$ до $-3{ }^{\circ} \mathrm{C}$, составляют 5-8,8 мас. \% $\mathrm{NaCl}-$ экв.

Парагенезис пирротина I продуктивной стадии с пиритом, арсенопиритом, халькопиритом и самородным золотом предполагает, что фугитивность серы $\left(\mathrm{SS}_{2}\right)$ в минералообразующей системе составляла от $10^{-14,3}$ до $10^{-7,6}$ при $300{ }^{\circ} \mathrm{C}[10,11]$. Парагенезисы теллуридов и сульфидов II продуктивной стадии образовались при фугитивности теллура $\left(f \mathrm{Te}_{2}\right)$ от $10^{-13}$ до $10^{-9,5}, f \mathrm{~S}_{2}-10^{-14,7}-10^{-8,7}$ при $250{ }^{\circ} \mathrm{C}$.

\section{Изотопный состав серы пирита и флюида}

Для определения изотопного состава сульфидной серы были отобраны монофракции пиритов продуктивных стадий месторождения Барсучий. Изотопный состав серы пиритов I продуктивной стадии варьирует от $+1,4$ до $+4,3 \%$, II продуктивной стадии - от $+4,3$ до $+4,6 \%$, т. е. образуют узкий интервал от $+1,4$ до $+4,6$ \%о (табл. 4 ).

Таблица 4. $\delta^{34}$ S (\%о) пиритов продуктивных стадий месторож дения Барсучий и расчетные оценки соответствующих значений $\mathrm{H}_{2} \mathrm{~S}$ водного флюида

Table 4. Sulfur isotopic composition of pyrite related to Ag-bea ring sustages and calculated $\delta^{34} \mathrm{~S}$ values of $\mathrm{H}_{2} \mathrm{~S}$ in aque ous fluid

\begin{tabular}{|c|c|c|c|c|c|}
\hline $\begin{array}{c}\text { Проба } \\
\text { Sample }\end{array}$ & $\begin{array}{c}\text { Стадии } \\
\text { Subtages }\end{array}$ & $\mathrm{T},{ }^{\circ} \mathrm{C} *$ & $\begin{array}{l}\text { Минерал } \\
\text { Minerals }\end{array}$ & $\begin{array}{c}\delta^{34} \mathrm{~S}, \% 0 \\
(\mathrm{CDT})\end{array}$ & $\begin{array}{c}\delta^{34} \mathrm{~S}_{\mathrm{H}_{2} \mathrm{~S}}, \% 0 \\
\quad(\mathrm{CDT})\end{array}$ \\
\hline BS-18 & \multirow{2}{*}{$\begin{array}{l}\text { I продуктив- } \\
\text { ная стадия } \\
\text { I Au-bearing } \\
\text { substage }\end{array}$} & $360-280$ & $\begin{array}{c}\text { Пирит I } \\
\text { Pyrite I }\end{array}$ & $+1,4$ & $+0,1 \ldots+0,4$ \\
\hline BS-18-1 & & $300-280$ & $\begin{array}{l}\text { Пирит II } \\
\text { Pyrite II }\end{array}$ & $+4,3$ & $+2,9 \ldots+3,0$ \\
\hline BS-21 & \multirow{2}{*}{$\begin{array}{c}\text { I продуктив- } \\
\text { ная стадия } \\
\text { I Au-bearing } \\
\text { substage }\end{array}$} & \multirow{2}{*}{$320-240$} & \multirow{2}{*}{$\begin{array}{l}\text { Пирит III } \\
\text { Pyrite III }\end{array}$} & $+4,3$ & $+2,7 \ldots+3,2$ \\
\hline BS-22 & & & & $+4,6$ & $+3,0 \ldots+3,5$ \\
\hline
\end{tabular}

Примечание. *-температуры гомогенизации включений в кварие.

Note. *-tomogenization temperatures of inclusions in quartz.
Изотопный состав серы сульфидов гидротермальных месторождений зависит от источника серы гидротермальной жидкости и условий осаждения минерала (температура осаждения, $\mathrm{pH}$ и $\mathrm{fO}_{2}$ и т. д.), т. е. в процессе минералообразования может происходить перераспределение изотопов серы в зависимости от нескольких факторов, которые необходимо учитывать [12-14]. Изотопный состав серы во флюиде $\left(\delta^{34} \mathrm{~S}_{\mathrm{H}_{2} \mathrm{~S}}\right)$, находящемся в равновесии с сульфидами в момент минералообразования, был рассчитан с использованием величин $\delta^{34} \mathrm{~S}$ для пиритов и температур гомогенизации включений в кварце в соответствии с уравнением фракционирования $[12,15]$, исходя из предположения, что в растворах преобладал $\mathrm{H}_{2} \mathrm{~S}: \Delta_{\text {пирит }-\mathrm{H}_{2} \mathrm{~S}}=\delta^{34} \mathrm{~S}_{\text {пирит }}-\delta^{34} \mathrm{~S}_{\mathrm{H}_{2} \mathrm{~S}}=0,4\left(10^{6} / \mathrm{T}^{2}\right)$.

Рассчитанные значения $\delta^{34} \mathrm{~S}_{\mathrm{H}_{2} \mathrm{~S}}$ флюида I продуктивной стадии варьируют от $+0,1$ до $3,0 \%$, флюида II продуктивной стадии - от $+2,7$ до $+3,5 \%$ (табл. 4 ), что свидетельствует об участии серы магматического $(0 \pm 5 \%$ л) либо мантийного $(0 \pm 3 \%$ ) происхождения $[12,13,16]$, т. е. соответствуют флюиду магматической природы (рис. 9).

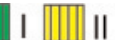

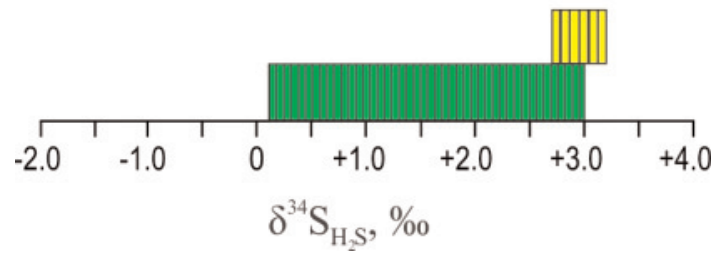

Pис.9. Изотопный состав серы рудообразующего флюида ( $\left.\delta^{34} S_{\mathrm{H} 2 \mathrm{~S}}\right)$, равновесного с сульфидами I и II продуктивных cmaduŭ

Fig. 9. Sulfur isotopic composition of ore-forming fluid ( $\left.\delta^{34} S_{\mathrm{H} 2 \mathrm{~S}}\right)$ in equilibrium with sulphides of I and II Au-bearing substages

\section{Обсуждение результатов}

Проведёнными исследованиями установлено, что прожилково-вкрапленное золото-сульфиднокварцевое оруденение штокверкового типа с единичными жилами сульфидно-кварцевого состава 
месторождения Барсучий в скарнах, апоскарновых метасоматитах и диоритах имеет гидротермальный генезис и с магнетит-скарновой формацией связано лишь пространственно. Золоторудная минерализация месторождения генетически связана с дорудными среднетемпературными углекислыми метасоматитами лиственит-березитового ряда, которые образуются по осадочно-вулканогенным породам, кварцевым диоритам и контактовым породам (скарны), локализующимся вдоль контактов интрузивных пород и известняков.

На месторождении Барсучий отложение самородного золота происходило в течение двух стадий минералообразования. С I продуктивной стадией связано весьма высокопробное (Ag до 5 мас. \% ) и высокопробное золото (Ag до 7 мас. \%), со II продуктивной стадией - высокопробное (Ag до 10 мас. \%), среднепробное ( $\mathrm{Ag}$ до 20 мас. \%) и низкопробное (Ag до 22 мас. \%) золото, а также калаверит, петцит и гессит. На месторождении преобладает самородная форма золота, а теллуридная имеет подчинённое значение. Калаверит ассоциирует с высокопробным золотом (902-932\%o).

Формирование продуктивных стадий месторождения Барсучий (I продуктивная стадия $360-280{ }^{\circ} \mathrm{C}$, II - 320-240 ${ }^{\circ} \mathrm{C}$ ) происходило из низкосреднеконцентрированных (1,7-10,5 мас. \% NaClэкв.) растворов состава $\mathrm{NaCl}-\mathrm{KCl}-\mathrm{H}_{2} \mathrm{O}$, содержащих углекислоту и метан. В процессе минералообразования происходило снижение температуры рудоносного флюида от ранних стадий к поздним.

Изотопный состав серы рудообразующего флюида $\left(\delta^{34} \mathrm{~S}, \% 0\right)$ продуктивных стадий попадают в узкий интервал от $+0,1$ до $+3,2 \%$, соответствующий флюиду магматической природы $(0 \pm 5 \%$ х характерный для месторождений золота связанных с интрузиями («intrusion related deposits») [17, 18].

В целом, на объектах ТРУ $[1,2,19,20]$, как и на других месторождениях золота в скарнах (Синюхинское, Чойское и др.) юга Сибири, оруденение золота является постскарновым, гидротермальным и широко проявлены поздние золото-висмут-теллуридные минеральные ассоциации [21, 22].

По минералого-геохимическим особенностям месторождение Барсучий относится к малосульфидной золото-сульфидно-кварцевой (березит-лиственитовой) формации и близко золото-висмутовому геохимическому типу [23-26], который по классификации зарубежных исследователей отвечает классу месторождений золота, парагенетически связанных с интрузиями («intrusion related deposits») [27].

Представителями золото-висмутового геохимического типа в России являются Эргелях, Курумское Тугучак, Басагуньинское, Чугулук, Неннели и Галечное (СВ России) жильные и Лево-Дыбинское, Тэутеджак (СВ России) штокверковые месторождения, которые приурочены к апикальным приконтактовым зонам гранитоидных плутонов либо к их краевым приконтактовым зонам, дайкам разного состава (гранит-порфиры, диабазы и т. д.) $[24,26-33]$.
Для вышеуказанных месторождений золото-висмутового геохимического типа России характерен малосульфидный (не более $3 \%$ ) состав руд и разнообразие минеральных форм висмута (самородный $\mathrm{Bi}, \mathrm{Bi}_{2} \mathrm{Te}_{3}, \mathrm{Bi}_{7} \mathrm{Te}_{3}, \mathrm{Bi}_{2} \mathrm{~S}_{3}, \mathrm{Bi}_{4} \mathrm{~S}_{3}, \mathrm{Bi}_{2} \mathrm{Te}_{2} \mathrm{~S}, \mathrm{Bi}_{4} \mathrm{Te}_{2} \mathrm{~S}$, $\mathrm{Pb}_{2} \mathrm{Bi}_{2} \mathrm{~S}_{5}$ и др.), и по составу продуктивных стадий они отнесены к висмут-сульфотеллурид-кварцевому минеральному типу [26, 32, 33]. Ранние продуктивные стадии этих месторождений представлены арсенид-сульфоарсенидными комплексами, которые содержат минералы Со и $\mathrm{Ni}$ с широким изоморфизмом $\mathrm{Fe}-\mathrm{Co}-\mathrm{Ni}$, поздние продуктивные стадии - золотовисмутовыми ассоциациями [33]. Образование золото-висмутовых месторождений происходит в широком интервале давлений (1700-90 бар) и температур (437- $155^{\circ} \mathrm{C}$, в основном, $400-250{ }^{\circ} \mathrm{C}$ ) из растворов с хлоридами $\mathrm{Na}$ и $\mathrm{K}$, содержащих $\mathrm{CO}_{2}$ и $\mathrm{CH}_{4}$, в широком диапазоне концентраций (46,0-1,1 мас. \%), при вариациях $\mathrm{fO}_{2}-\mathrm{S}_{2}[32,33]$. Присутствие углекислоты является повсеместной особенностью золоторудных месторождений, связанных с интрузиями («intrusion related deposits») $[18,34,35]$.

\section{Заключение}

Штокверковое золото-сульфидно-кварцевое оруденение месторождения Барсучий, локализованного в эндо- и экзоконтакте интрузивных пород раннетаннуольского комплекса $\left(\mathrm{O}_{1} t n\right)$, имеет гидротермальный генезис и со скарновой формацией связано лишь пространственно. Золоторудная минерализация месторождения сопряжена с процессами березитизации-лиственитизации, отложение минералов $\mathrm{Au}$ и $\mathrm{Ag}$ происходило в течение двух стадий минералообразования. По составу продуктивных стадий Барсучий отвечает золото-пирротин-пирит-халькопиритовому минеральному типу с теллуридами $\mathrm{Au}$ и $\mathrm{Ag}$, неограниченными твёрдыми растворами минералов ряда теллуровисмутит-теллурантимон $\left(\mathrm{Bi}_{2} \mathrm{Te}_{3}-\mathrm{Sb}_{2} \mathrm{Te}_{3}\right)$. Впервые на этом месторождении выявлены: арсенопирит, калаверит, петцит, гессит, теллуровисмутит, теллурантимон и кобальтин.

Полученные данные по флюидным включениям и минеральным парагенезисам свидетельствуют о том, что рудоотложение на месторождении происходило из водных растворов состава $\mathrm{NaCl}-\mathrm{KCl}-\mathrm{H}_{2} \mathrm{O}$, содержащих углекислоту и метан, с солёностью 1,7-10,5 мас. \% NaCl-экв., на фоне снижения температур в интервале $360-240{ }^{\circ} \mathrm{C}$ (I продуктивная стадия - $360-280^{\circ} \mathrm{C}$, II продуктивная стадия $\left.-320-240{ }^{\circ} \mathrm{C}\right)$ при вариациях $\mathrm{fO}_{2}, \mathrm{fS}_{2}$ и $f \mathrm{Te}_{2}$. Изотопный состав серы рудообразующего флюида предполагает участие в рудном процессе серы магматического происхождения.

Авторы благодарны к.г.-м.н. И.А. Блинову за проведение микрозондовых анализов. "Минералого-геохилические и изотопные исследования поддержаны РФФИ (№ 17-45170970 p а), исследования флюидных включений выполнены по государственным заданиям ИГМ СО РАН (03302016-0002) и ИМин ЮУ ФНЦ МиГ УрО РАН (2019-2021 г2.), экспедиционные работы - по государственному заданию ТувИКОПР СО РАН (0384-2016-0012)". 


\section{СПИСОК ЛИТЕРАТУРЫ}

1. Рудно-метасоматическая и геохимическая зональность золоторудных полей и месторождений складчатых поясов Сибири А.Ф. Коробейников, Ю.С. Ананьев, А.И. Гусев, В.Г. Ворошилов. - Томск: Изд-во Томского политехнического университета, 2013. -458 с.

2. Гаськов И.В. Новые данные о соотношении скарновой и золоторудной минерализации на Тарданском месторождении (Cеверо-Восточная Тува) // Геология и геофизика. - 2008. T. 49. - № 12. - C. 1227-1237.

3. Кильчичаков К.М., Токунов В.Ф., Плеханов А.И. Результаты оценки Тарданского золоторудного месторождения и поисков золота в бассейне р. Бай-Сют. - Кызыл: Изд-во ТГРЭ, 1967. $150 \mathrm{c.}$

4. Руднев С.Н., Серов П.А., Киселёва В.Ю. Венд-раннепалеозойский гранитоидный магматизм Восточной Тувы // Геология и геофизика. - 2015. - Т. 56. - № 9. - С. 1572-1600.

5. Петровская Н.В. Самородное золото. - М.: Наука, 1973. 348 c.

6. Борисенко А.С. Анализ солевого состава растворов газово-жидких включений в минералах методом криометрии // Использование методов термобарогеохимии при поисках и изучении рудных месторождений / под ред. Н.П. Лаверова. - М.: Недра, 1982. - C. 37-46.

7. Bodnar R.J., Vityk M.0. Interpretation of microthermometric data for $\mathrm{H}_{2} \mathrm{O}-\mathrm{NaCl}$ fluid inclusions // Fluid Inclusions in Minerals, Methods and Applications / Eds. B. De Vivo, M.L. Frezzotti. Blacksburg: Virginia Polytechnic Institute \& State University publ., 1994. - P. 117-130.

8. Парагенезисы теллуридов золота и серебра в золоторудном месторождении Флоренсия (Республика Куба) / Н.С. Бортников, Х.Л. Крамер, А.Д. Генкин, Л.Я. Крапива, М. Санта-Крус // Геология рудных месторождений. - 1988. - № 2. - С. 49-61.

9. Реддер Э. Флюидные включения в минералах. - М.: Мир, 1978. - T. 1. - 360 c.

10. Barton P.B., Skinner B.J. Sulfide mineral stabilities // Geochemistry of Hydrothermal Ore Deposits / Ed. by H.L. Barnes. - New York: John Willey and Sons, 1979. - P. 278-403.

11. Afifi A.M., Kelly W.C., Essene E.J. Phase relations among tellurides, sulfides, and oxides: I. Thermochemical data and calculated equilibria // Economic Geology. - 1988. - V. 83. - P. 377-394.

12. Ohmoto H., Rye R.0. Isotopes of sulfur and carbon // Geochemistry of hydrothermal ore deposits. - N.Y.: John Wiley and Sons, 1979. - P. 509-567.

13. Ohmoto H. Stable isotope geochemistry of ore deposits // Review Mineralogy. - 1986. - V. 16. - P. 491-560.

14. Hoefs J. Stable Isotope Geochemistry. - Berlin; Heidelberg: Springer-Verlag, 2009. - 281 p.

15. Li Y., Liu J. Calculation of sulfur isotope fractionation in sulfides // Geochimica Cosmochimica Acta. - 2006. - V. 70. P. 1789-1795.

16. Chaussidon M., Albarède F., Sheppard S.M.F. Sulfur isotope heterogeneity in the mantle from ion microprobe measurements of sulphide inclusions in diamonds // Nature. - 1987. - V. 330. P. 242-244

17. Newberry R.J., McCoy D.T., Brew D.A. Plutonic-hosted gold ores in Alaska: Igneous versus metmorphic origins // Proc. of the Sapporo International Conference on Mineral Resources of the NW Pacific Rim. Resource Geology, Special Issue / Eds. S. Ishihara, G.K. Czamanske. - 1995. - V. 18. - P. 57-100.

18. Plutonic-related gold deposits of Interior Alaska, Mineral Deposits of Alaska / D. McCoy, R.J. Newberry, P. Layer, J.J. DiMarchi, A. Bakke, S. Masterman, D.L. Minehane // Economic Geology. - 1997. - V. 9. - P. 191-241.

19. Кужугет Р.В., Ооржак Ш.Н. Золотоносные минеральные ассоциации Тарданского гидротермального месторождения (Вос- точная Тува) // Региональная экономика: технологии, экономика, экология и инфраструктура: Материалы II Международной научно-практической конференции. - Кызыл: Изд-во Тувинского института комплексного освоения природных ресурсов СО РАН (ТувИКОПР СО РАН), 2017. - С. 181-186.

20. Минералого-геохимические особенности и РТХ-условия формирования золото-сульфидно-кварцевого рудопроявления Тардан-2 (Северо-Восточная Тува) / Р.В. Кужугет, И.Р. Прокопьев, А.А. Редина, Ш.Н. Ооржак / Геология, магматизм и металлогения Центра Азии. 2018: Рудно-магматические системы Сангилена (щелочные интрузивы, карбонатиты): Материалы I Всероссийской полевой конференции с международным участием. - Кызыл: Изд-во Тувинского института комплексного освоения природных ресурсов СО РАН (ТувИКОПР СО РАН), 2018. - C. 72-76.

21. Гусев А.И., Табакаева Е.М. Геохимия акцессорного пирита лампрофиров Чойского скарнового золото-теллуридного месторождения Горного Алтая // Международный журнал прикладных и фундаментальных исследований. - 2016. - № 7-3. C. 435-439.

22. Калинин Ю.А., Наумов Е.А., Некипелова А.В. Аи-Ві-Те минерализация на $\mathrm{Au}-\mathrm{Cu}$-скарновых месторождениях (на примере Синюхинского рудного узла) // Основные проблемы в учении об эндогенных рудных месторождениях: новые горизонты: Материалы Всероссийской конференции, посвященной 120-летию со дня рождения выдающегося российского ученого академика А.Г. Бетехтина. - М.: Институт геологии рудных месторождений, петрографии, минералогии и геохимии РАН (ИГЕМ РАН), 2017. - С. 279-282.

23. Спиридонов Э.М. Обзор минералогии золота в ведущих типах $\mathrm{Au}$ минерализации // Золото Кольского полуострова и сопредельных регионов: Труды Всероссийской (с международным участием) научной конференции, посвящённой 80-летию Кольского НЦ РАН. - Апатиты, 26-29 сентября 2010. - Апатиты: Изд-во К\&M, 2010. - С. 143-171.

24. Гамянин Г.Н., Гончаров В.И., Горячев Н.А. Золото-редкометалльные месторождения Северо-Востока России // Тихоокеанская геология. - 1998. - Т. 17. - № 3. - С. 94-103.

25. Условия зарождения и эволюции гранитоидных золоторудномагматических систем в мезозоидах Северо-Востока Азии / Г.Н. Гамянин, Н.А. Горячев, А.Г. Бахарев, П.П. Колесниченко, А.И. Зайцев, Е.Н. Диман, Н.В. Бердников. - Магадан: Северо-восточный комплексный научно-исследовательский институт ДВО РАН (СВКНИИ ДВО РАН), 2003. - 196 с.

26. Горячев Н.А., Гамянин Г.Н. Золото-висмутовые (золото-редкометалльные) месторождения Северо-Востока России: типы и перспективы промышленного освоения // Золоторудные месторождения Востока России. - Магадан: Северо-восточный научный центр ДВО РАН (СВНЦ ДВО РАН), 2006. - С. 50-62.

27. Lang J.R., Baker T. Intrusionrelated gold systems: the present level of understanding // Mineralium Deposita. - 2001. - V. 36. P. 477-489.

28. Granitoid-related gold lode deposits over the Northern pacific marginal areas / N.A. Goryachev, R.J. Newberry, G.N. Gamyanin, P.W. Layer, D.T. McCoy, S.E. Church // Metallogeny of the Pacific Northwest. Tectonics, Magmatism and Metallogeny of active continental margins. Proceedings of the Interim IAGOD Conference. - Vladivostok, 1-20 September, 2004. - Vladivostok: Dalnauka, 2004. - P. 199-201.

29. Золото-висмутовый тип оруденения в юго-восточной части Восточного Саяна / Б.Б. Дамдинов, Б.Л. Гармаев, А.Г. Миронов, 3.Б. Дашинимаев // ДАН. - 2009. - Т. 425. - № 2. C. 208-212

30. Гармаев Б.Л., Дамдинов Б.Б., Миронов А.Г. Золото-висмутовое проявление пограничное (Восточный Саян): состав и связь с магматизмом // Геология рудных месторождений. - 2013. T. 55. - № 6. - C. 533-545. 
31. Гамянин Г.Н., Фридовский В.Ю., Викентьева О.В. Благороднометалльная минерализация Адыча-Тарынской металлогенической зоны: геохимия стабильных изотопов, флюидный режим и условия рудообразования // Геология и геофизика. 2018. - T. 59. - № 10. - C. 1586-1605.

32. Intrusion-related gold-bismuth deposits of North-East Russia: PTX parameters and sources of hydrothermal fluids / 0.V. Vikent'eva, V.Yu. Prokofiev, G.N. Gamyanin, N.A. Goryachev, N.S. Bortnikov // Ore Geology Reviews. - 2018. - V. 100. P. $240-259$.

33. Гамянин Г.Н., Викентьева О.В., Прокофьев В.Ю. Изотопногеохимические особенности рудообразующего флюида золотовисмутовых месторождений Северо-Востока России // Материалы VII Всероссийской научно-практической конференции, посвященной 60-летию Института геологии алмаза и благородных металлов Сибирского отделения Российской академии наук. - Якутск, 5-7 Апреля 2017. - Якутск: Изд-во СевероВосточного федерального университета, 2017. - С. 46-51.

34. Intrusionrelated gold deposits associated with tungsten-tin provinces / J.F.H. Thompson, R.H. Sillitoe, T. Baker, J.R. Lang, J.K. Mortensen // Mineralium Deposita. - 1999. - V. 34. P. 323-334.

35. An exploration model for intrusion-related gold systems / J.R. Lang, T. Baker, C.J.R. Hart, J.K. Mortensen // Society of Economic Geologists Newsletter. - 2000. - V. 40 (1). - P. 6-15.

Поступила 14.07.2019 2.

\section{Информация об авторах}

Kyжуге P.B., кандидат геолого-минералогических наук, ведущий научный сотрудник лаборатории геодинамики, магматизма и рудообразования Тувинского института комплексного освоения природных ресурсов СО PAH.

Прокопьев И.Р., кандидат геолого-минералогических наук, научный сотрудник лаборатории рудоносности щелочного магматизма Института геологии и минералогии им. В.С. Соболева СО РАН, старший преподаватель Геолого-геофизического факультета Новосибирского государственного университета.

Peдина A.A., младший научный сотрудник лаборатории рудоносности щелочного магматизма Института геологии и минералогии им. В.С. Соболева СО РАН.

Анкушева H.H., кандидат геолого-минералогических наук, научный сотрудник лаборатории минералогии рудогенеза Института минералогии ЮУ ФНЦ МиГ, старший преподаватель Геологического факультета ЮжноУральского государственного университета. 
UDC 553.2: $549.283(571.52)$

\title{
MINERALOGICAL AND GEOCHEMICAL FEATURES AND CONDITIONS OF BARSUCHY GOLD-SULFIDE-QUARTZ DEPOSIT FORMATION (NORTH-EASTERN TUVA)
}

Renat V. Kuzhuget', rkuzhuget@mail.ru

Ilya R. Prokopyev ${ }^{2,3}$, prokopev_ilya@mail.ru

Anna A. Redina², anna-red@outlook.com

\author{
Natalia N. Ankusheva ${ }^{4,5}$, \\ ankusheva@mail.ru \\ 1 Tuvinian Institute for Exploration of Natural Resources SB RAS, \\ 117 a, Internatsionalnaya street, Kyzyl, 667007, Russia. \\ 2 VS Sobolev Institute of Geology and Mineralogy SB RAS, \\ 3, Academician Koptyug Avenue, Novosibirsk, 630090, Russia. \\ ${ }^{3}$ Novosibirsk State University, \\ 1, Pirogov street, Novosibirsk, 630090, Russia. \\ ${ }^{4}$ Institute of Mineralogy SU FRC MG, \\ 1, Ilmensky Reserve, Miass, 456317, Russia. \\ ${ }^{5}$ South Urals State University in Miass, \\ 10, 8 lyulya street, Miass, 456316, Russia.
}

Gold ore objects in skarns are widespread in geological structures of the Eastern Tuva, but their estimation is considerable difficult due to poor information about mineralogical, geochemical and petrographic peculiarities of ores. The study of the genesis and conditions of gold deposits formation, which are located in skarns, is one of the fundamental scientific disciplines in geological science.

The aim of the study is to examine the mineralogical and geochemical peculiarities and conditions of ore formation of the Barsuchy deposit in North-Eastern Tuva.

Methods: field work, detailed mineralogical study of ore mineralization using Tescan Vega 3 SBU scanning electron microscope with EMF Oxford Instruments X-act. PT conditions of mineral associations' formation are determined by fluid inclusion study as well as using geofugometers and mineral paragenesis.

Results. The authors have manifested that the gold mineralization of the Barsuchy deposit is post-skarned and has a hydrothermal genesis forming a vein-disseminated mineralization of stockwork-type in quartz-diorites, contact (hornfels, skarns) and hydrothermalmetasomatic formations. Near-ore processes are expressed in beresitization and listwanitization of quartz-diorites, skarns and carbonate rocks. The native gold was formed during two stages. According to the composition of the productive mineral associations, Barsuchy deposit is related to a gold-pyrrhotite-pyrite-chalcopyrite type with the AuTe ${ }_{2}$ calaverite, petzite, hessite and minerals of the tellurobismuthite-tellurantimony series. The gold-quartz-sulfide mineralization is formed due to aqueous fluids with $\mathrm{Na}$ and $\mathrm{K}$ chlorides containing $\mathrm{CO}_{2}$ and $\mathrm{CH}_{4}$ with a salinity of 1-10,5 wt. \% NaCl-eq. accompanied with Redox-potential changes and the variations of $f \mathrm{~S}_{2}, f \mathrm{Se}_{2}$, $f \mathrm{Te}$, and temperature fall of the ore-bearing fluid (the first productive stage is $360-280{ }^{\circ} \mathrm{C}$, the second one $-320-240{ }^{\circ} \mathrm{C}$ ). According to mineralogical and geochemical features, Barsuchy deposit belongs to gold-sulfide-quartz formation (with less than $5 \%$ sulfides) and is close to Au-Bi geochemical type of deposits.

Key words:

Native gold, tellurides, fluid inclusions, quartz, Tuva.

This work is supported by Russian Foundation for Basic Researches (No.17-45-170970 p_a).

\section{REFERENCES}

1. Korobeynikov A.F., Ananiev Yu.S., Gusev A.I., Voroshilov V.G. Rudno-metasomaticheskaya i geokhimicheskaya zonalnost zolotorudnykh poley i mestorozhdeniy skladchatykh poyasov Sibiri [Oremetasomatic and geochemical zoning of gold fields and deposits of fold belts of Siberia]. Tomsk, Tomsk Polytechnic University Publ., 2013. 458 pp.

2. Gas'kov I.V. New data on the correlation of skarn and gold mineralization at the Tardan deposit (northeastern Tuva). Russian Geology and Geophysics, 2008, vol. 49, no 12, pp. 923-931.
3. Kilchichakov K.M., Tokunov V.F., Plekhanov A.I. Rezultaty otsenki Tardanskogo zolotorudnogo mestorozhdeniya i poiskov zolota $v$ basseyne r. Bay-Syut [Evaluation results of the Tardan gold deposit and the search for gold in the Bai-Syut river basin]. Kyzyl, TGRE Publ., 1966. 150 p.

4. Rudnev S.N., Kiseleva V., Serov P.A. Vendian-Early Paleozoic granitoid magmatism in Eastern Tuva. Russian Geology and Geophysics, 2015, vol. 56, no. 9, pp. 1232-1255.

5. Petrovskaya N.V. Samorodnoe zoloto [Native Gold]. Moscow, Nauka Publ., 1973. 348 p. 
6. Borisenko A.S. Analiz solevogo sostava rastvorov gazovo-zhidkikh vklyucheniy v mineralakh metodom kriometrii [Analysis of salt composition of solutions of gas-liquid inclusions in minerals using the cryometry method]. Ispolzovanie metodov termobarogeokhimii pri poiskakh i izuchenii rudnykh mestorozhdeniy [Use of thermobarogeochemistry methods for prospecting and studying ore deposits]. Ed. by N. Laverov. Moscow, Nauka Publ., 1982. pp. 37-46.

7. Bodnar R.J., Vityk M.O. Interpretation of microthermometric data for $\mathrm{HO}-\mathrm{NaCl}$ fluid inclusions. Fluid Inclusions in Minerals, Methods and Applications. Eds. B. De Vivo, M.L. Frezzotti. Blacksburg, Virginia Polytechnic Institute \& State University Publ., 1994. pp. 117-130.

8. Bortnikov N.S., Kramer Kh., Genkin A.D., Krapiva L.Ya., Santa Cruz M. Paragenesis of Gold and Silver Tellurides in the Florencia Gold Deposit, the Republic of Cuba. International Geology Review, 1988, vol. 30 (3), pp. 294-306.

9. Roedder E. Flyuidnye vklyucheniya $v$ mineralakh [Fluid Inclusions in Minerals]. Moscow, Mir Publ., 1987. 360 p.

10. Barton P.B., Skinner B.J. Sulfide mineral stabilities. Geochemistry of Hydrothermal Ore Deposits. Ed. by H.L. Barnes. New York, John Willey and Sons, 1979. pp. 278-403.

11. Afifi A.M., Kelly W.C., Essene E.J. Phase relations among tellurides, sulfides, and oxides: I. Thermochemical data and calculated equilibria; II. Applications to telluride-bearing ore deposits. Economic Geology, 1988, vol. 83, pp. 377-394.

12. Ohmoto H., Rye R.O. Isotopes of sulfur and carbon. Geochemistry of hydrothermal ore deposits. N.Y., John Wiley and Sons, 1979. pp. 509-567.

13. Ohmoto H. Stable isotope geochemistry of ore deposits. Review Mineralogy, 1986, vol. 16, pp. 491-560.

14. Hoefs J. Stable Isotope Geochemistry. Berlin, Heidelberg, Springer-Verlag, 2009. $281 \mathrm{p}$.

15. Li Y., Liu J. Calculation of sulfur isotope fractionation in sulfides. Geochimica Cosmochimica Acta, 2006, vol. 70, pp. 1789-1795.

16. Chaussidon M., Albarède F., Sheppard S.M.F. Sulfur isotope heterogeneity in the mantle from ion microprobe measurements of sulphide inclusions in diamonds. Nature, 1987, vol. 330, pp. 242-244.

17. Newberry R.J., McCoy D.T., Brew D.A. Plutonic-hosted gold ores in Alaska: Igneous versus metmorphic origins. In: Ishihara S., Czamanske G.K. (Eds.), Proceedings of the Sapporo International Conference on Mineral Resources of the NW Pacific Rim. Resource Geology, Special Issue, 1995, vol. 18, pp. 57-100.

18. McCoy D., Newberry R.J., Layer P., DiMarchi J.J., Bakke A., Masterman S., Minehane D.L. Plutonic-related gold deposits of Interior Alaska, Mineral Deposits of Alaska. Economic Geology, 1997, vol. 9, pp. 191-241.

19. Kuzhuget R.V., Oohzhak Sh.N. Zolotonosnye mineralnye assotsiatsii Tardanskogo gidrotermalnogo mestorozhdeniya (Vostochnaya Tuva) [Golden mineral associations of the Tardan hydrothermal deposit (Eastern Tuva)]. Regionalnaya ekonomika: tekhnologii, ekonomika, ekologiya i infrastruktura. Materialy II Mezhdunarodnoy nauchno-prakticheskoy konferentsii [Regional economy: Technologies, economy, ecology, and infrastructure: Proceedings of the 2 International Scientific and Practical Conference]. Kyzyl, Tuvinian Institute for Exploration of Natural Resources SB RAS (TuvIENR SB RAS) Publ., 2017. pp. 181-186.

20. Kuzhuget R.V., Prokopyev I.R., Redina A.A. Mineralogo-geokhimicheskie osobennosti i RTH-usloviya formirovaniya zoloto-sulfidno-kvartsevogo rudoproyavleniya Tardan-2 (Severo-Vostochnaya Tuva) [Mineralogical-geochemical features and PTX formation conditions of the Tardan-2 gold-sulphide-quartz ore occurrence (North-Eastern Tuva)]. Geologiya, magmatizm i metallogeniya Tsentra Azii. 2018: Rudno-magmaticheskie sistemy Sangilena (shchelochnye intruzivy, karbonatity). Materialy I
Vserossiyskoy polevoy konferentsii s mezhdunarodnym uchastiem [Geology, magmatism and metallogeny of Central Asia. 2018: Ore-magmatic systems of the Sangilen (alkaline intrusives, carbonatites): proceedings of the first all-Russia field conference with international participation]. Kyzyl, Tuvinian Institute for Exploration of Natural Resources SB RAS (TuvIENR SB RAS) Publ., 2018. pp. 279-282.

21. Gusev A.I., Tabakaeva E.M. Geochemistry of accessory pyrites lamprophyres Choyskoe skarn gold-telluride deposit of Mountain Altai. International journal of applied and fundamental research, 2016, no 7-3, pp. 435-439. In Rus.

22. Kalinin Yu.A., Naumov E.A., Nekipelova A.V. Au-Bi-Te mineralizatsiya na $\mathrm{Au}$-Cu-skarnovykh mestorozhdeniyakh (na primere $\mathrm{Si}$ nyukhinskogo rudnogo uzla) [Au-Bi-Te mineralization in $\mathrm{Au}-\mathrm{Cu}-$ skarn deposits (by the example of the Sinyukhin ore site)]. Osnovnye problemy $v$ uchenii ob endogennykh rudnykh mestorozhdeniyakh: novye gorizonty. Materialy Vserossiyskoy konferentsii, posvyashchennoy 120-letiyu so dnya rozhdeniya vydayushchegosya rossiyskogo uchenogo akademika A.G. Betekhtina [Main problems in studying endogenous ore deposits: new horizons. Proc. of the All-Russian Conference dedicated to the $120^{\text {th }}$ anniversary of the outstanding Russian scientist Academician A.G. Betehtin]. Moscow, Institute of Geology, of Ore Deposits, Petrography, Mineralogy and Geochemistry RAS (IGEM RAS) Publ., 2017. pp. 279-282.

23. Spiridonov E.M. Obzor mineralogii zolota v vedushchikh tipakh Au mineralizatsii [Review of gold mineralogy in major types of $\mathrm{Au}$ mineralization]. Zoloto Kolskogo poluostrova $i$ sopredelnykh regionov. Trudy Vserossiiskoy (s mezhdunarodnym uchastiem) nauchnoy konferentsii, posvyashchennoy 80-letiyu Kolskogo NC RAN [Gold of the Kola Peninsula and Adjacent Regions. Proc. of the Russian (with Non-Russian Participants) Conference Dedicated to the $80^{\text {th }}$ Anniversary of the Kola Scientific Center (Russian Academy of Sciences)]. Apatity, K\&M Publ., 2010. pp. 143-171.

24. Gamyanin G.N., Goncharov V.I., Goryachev N.A. Gold-rare-metal deposits of Northeast Russia. Pacific Geology, 1998, no. 3, pp. 94-103. In Rus.

25. Gamyanin G.N., Goryachev N.A., Bakharev A.G., Kolesnichenko P.P., Diman E.N., Zaitsev A.I., Berdnikov N.V. Usloviya zarozhdeniya i evolyutsii granitoidnykh zolotorudno-magmaticheskikh sistem v mezozoidakh Severo-Vostoka Azii [Conditions of Origin and Evolution of Gold Ore Magmatic Granitoid Systems in North East Asia Mesozoids]. Magadan, North-East Interdisciplinary Scientific Research Institute Far East Branch RAS (NEISRI FEB RAS) Publ., 2003. 196 p.

26. Goryachev N.A., Gamyanin G.N. Zoloto-vismutovye (zoloto-redkometallnye) mestorozhdeniya Severo-Vostoka Rossii: tipy i perspektivy promyshlennogo osvoeniya [Gold-Bismuth (Gold-Raremetal) Deposits of North East Russia: Types, and Exploration Perspectives. Gold ore Deposits of East Russia]. Magadan, NorthEast Interdisciplinary Scientific Research Institute FEB RAS (NEISRI FEB RAS) Publ., 2006. pp. 50-62.

27. Lang J.R., Baker T. Intrusion related gold systems: the present level of understanding. Mineralium Deposita, 2001, vol. 36, pp. 477-489.

28. Goryachev N.A., Newberry R.J., Gamyanin G.N., Layer P.W., McCoy D.T., Church S.E. Granitoid-related gold lode deposits over the Northern pacific marginal areas. Metallogeny of the Pacific Northwest. Tectonics, Magmatism and Metallogeny of active continental margins. Proceedings of the Interim IAGOD Conference. Vladivostok, 1-20 September, 2004. Vladivostok, Dalnauka Publ., 2004. pp. 199-201.

29. Damdinov B.B., Garmaev B.L., Mironov A.G., Dashinimaev Z.B. Gold-bismuth mineralization in the southeastern part of the Eastern Sayan. Doklady Earth Sciences, 2009, vol. 425, no. 2, pp. 256-259.

30. Garmaev B.L., Damdinov B.B., Mironov A.G. Pogranichnoe AuBi occurrence, Eastern Sayan: Composition and link to magmatism. Geology of Ore Deposits, 2013, vol. 55, no. 6, pp. 445-466. 
31. Gamyanin G.N., Fridovsky V.Yu., Vikent'eva 0.V. Noble-metal mineralization of the Adycha-Taryn metallogenic zone: Geochemistry of stable isotopes, fluid regime, and ore formation conditions. Russian Geology and Geophysics, 2018, vol. 59, no. 10, pp. 1271-1287.

32. Vikent'eva 0.V., Prokofiev V.Yu., Gamyanin G.N., Goryachev N.A., Bortnikov N.S. Intrusion-related gold-bismuth deposits of North-East Russia: PTX parameters and sources of hydrothermal fluids. Ore Geology Reviews, 2018, vol. 100, pp. 240-259.

33. Gamyanin G.N., Vikenteva 0.V., Prokofiev V.Yu. Izotopno-geokhimicheskie osobennosti rudoobrazuyushchego flyuida zolotovismutovykh mestorozhdeniy Severo-Vostoka Rossii [Isotopic-geochemical features of the ore-forming fluid of gold-bismuth deposits of the North-East of Russia]. Materialy VII Vserossiyskoy nauchno-prakticheskoy konferentsii, posvyashchennoy 60-letiyu
Instituta geologii almaza i blagorodnykh metallov Sibirskogo otdeleniya Rossiyskoy akademii nauk [Materials of the VII All-Russian Scientific and Practical Conference dedicated to the $60^{\text {th }}$ anniversary of the Institute of Geology of Diamond and Precious Metals of the of the Siberian Branch of the Russian Academy of Sciences]. Yakutsk, 5-7 April 2017. Yakutsk, North-Eastern Federal University (NEFU) Publ., 2017. pp. 46-51.

34. Thompson J.F.H., Sillitoe R.H., Baker T., Lang J.R., Mortensen J.K. Intrusionrelated gold deposits associated with tungstentin provinces. Mineralium Deposita, 1999, vol. 34, pp. 323-334.

35. Lang J.R., Baker T., Hart C.J.R., Mortensen J.K. An exploration model for intrusion-related gold systems. Society of Economic Geologists Newsletter, 2000, vol. 40 (1), pp. 6-15.

Received: 14 July 2019.

\section{Information about the authors}

Renat V. Kuzhuget, Cand. Sc., lead researcher, Tuvinian Institute for Exploration of Natural Resources SB RAS.

Ilya R. Prokopyev, Cand. Sc., researcher, VS Sobolev Institute of Geology and Mineralogy SB RAS; senior lecturer, Novosibirsk State University.

Anna A. Redina, junior researcher, VS Sobolev Institute of Geology and Mineralogy SB RAS.

Natalia N. Ankusheva, Cand. Sc., scientist, Institute of Mineralogy SU FRC MG; senior researcher, South-Urals State University. 